المقوملت المشجعة عل التوسعف زراعة محصط زهرة الشعس الزبق بن مزاريم بهضقرى مركزى أبو الملامير وكثر الدوار بمحانغلة البحيرة

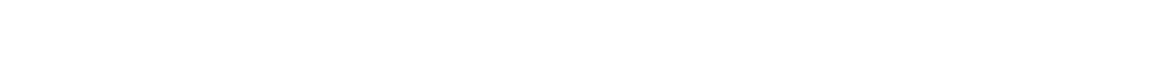

لأهمية كل مجموعة منها س,

وش,

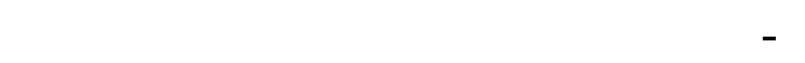

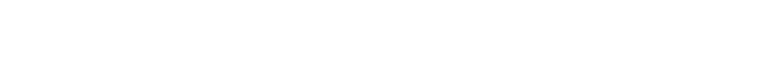

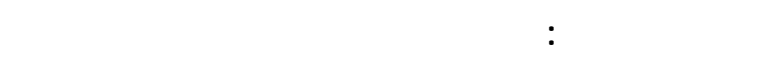

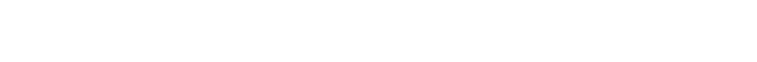

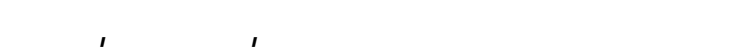

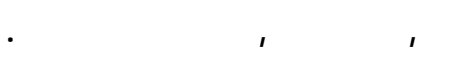

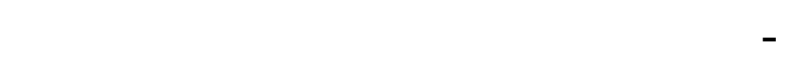
معلوماتهر عن زراعة محصط زهرة الثشس الزبق هم: تجار المستلزملت الزراعية، وكبار الزراع بالقربة، والخبرة الشخصية، ولأفارب والجيرل.

ع -جاعت أهم المعوقلت الث تولجه المبحوثين عند التوسع ف المبرن

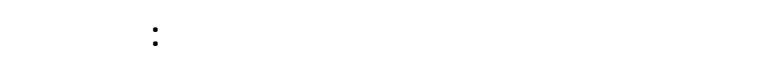

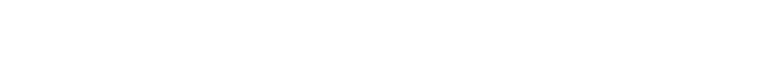

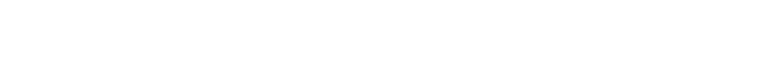
والآلت الهشربة الق تصيب المحصرل، والنخفلهن إنتلجية

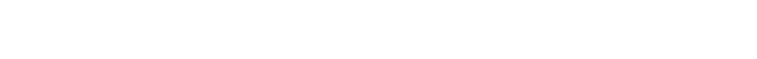

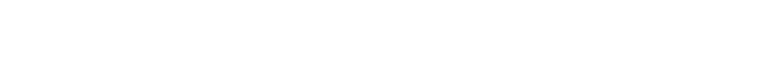
الإشالية الخاصة بالمحصط، وقلة توفرمصانع حكومي ة

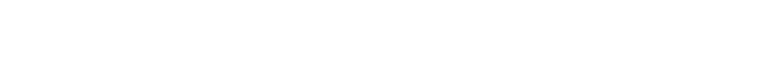
ظلم الزراعة التعلفية للمحصط. الهاملت الفتاحية:مقومات التوسع - زهرة الثهس الزبقي الفقدة والهثكلة البحثية

تعتبر المحاصيل الزيتية لحد المحاصيل الغذائية الهلم فى مصر، حيث تعد مصدراً رئيسيً لإنتاج الزيوت النباتية

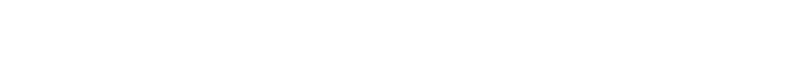

الماضص المرص

أستهف هذا البهث تحصيد درجة أهمية المقوملت المشجعة عل التوسع ف زراعة محصط زهرة الـ ششس الزبتهم نم ن وجهة ظلر المبحوثن، وتحيد درجة ت وفر نال لك الفقوم لت

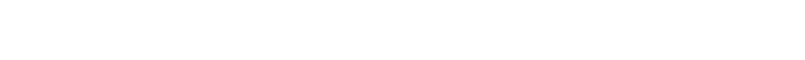

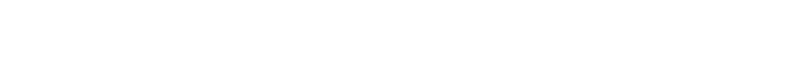

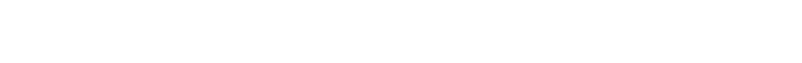
عند التوسعف زراعةمحصط زهرة الثشس الزيقدن وجهنة قالرهم. وقد أجرى البهث فمحاثلة البحيرة بإعتبارهام ن أكب ـر

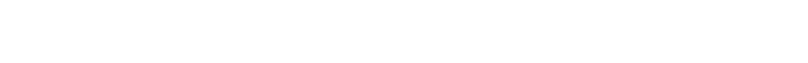

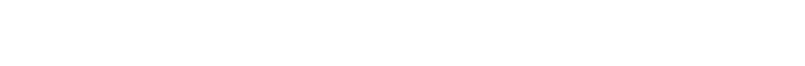

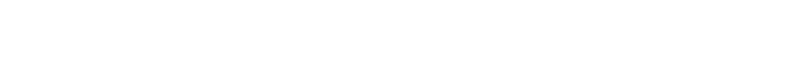

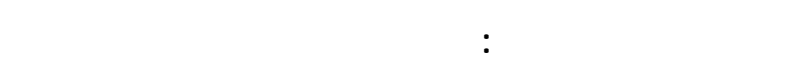
وسيى غازى، ومارصن بمركزكمر الدوار، وم جمع البيلن لت عنطريق الإستبيلن بالةقلبلة الشخصية لعينة عشوائية منتالمة

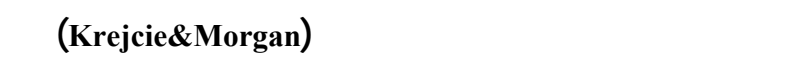

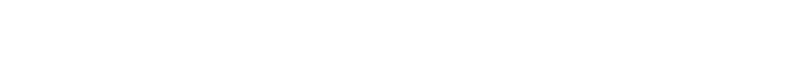

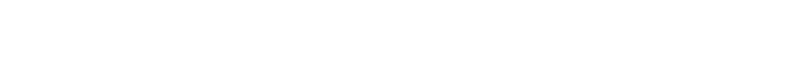
بالتكرارل والنسب المئوية، والمتوسط الهسلب، والإنح رله المعيارى، والمتوطط النسمف تحالل البيلنات وعرض النتئج.

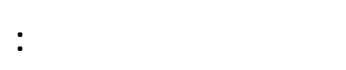

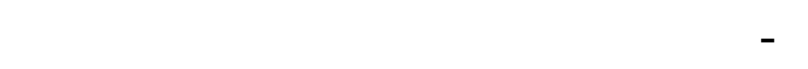

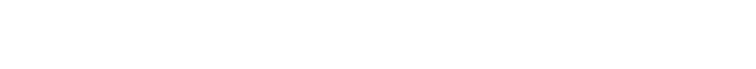

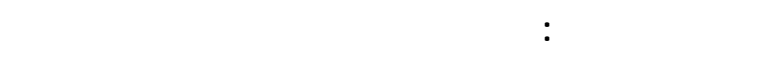

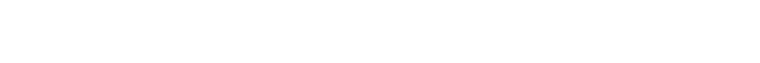

معرد بحوث الإششاد الزراعى والتمية الريفية - مركز البحوث الزراعية

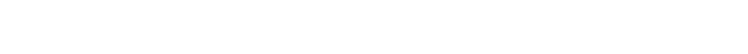




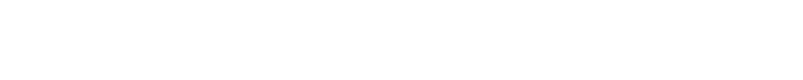

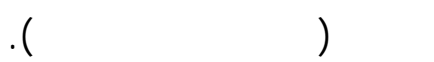
وهذه الزيادة مرجعها لحدوث العدي دـ مـ نـ التغي -رات

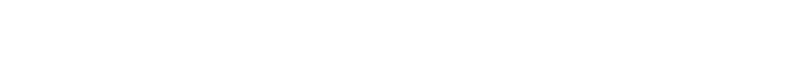

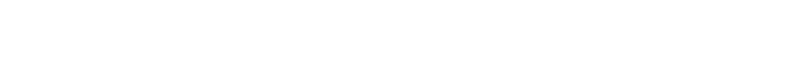

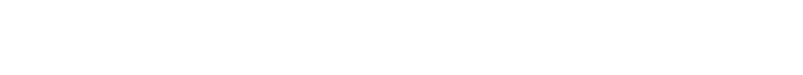

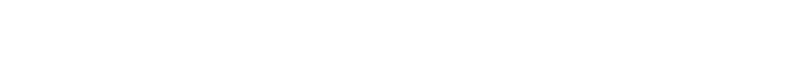

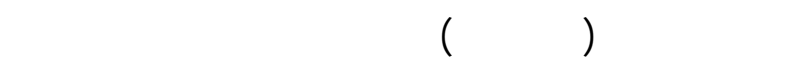

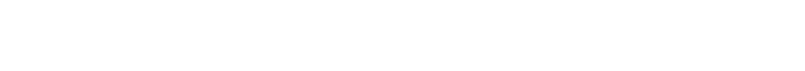

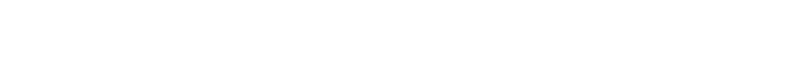

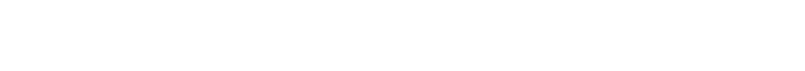

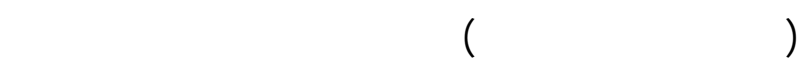

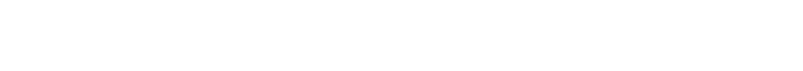

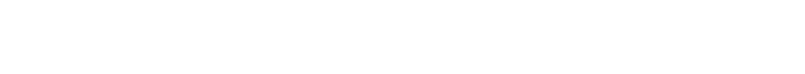

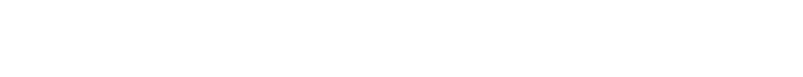
الضغط على المولطنين وخاصة مح دودى ال ـنل مـ ـنهم

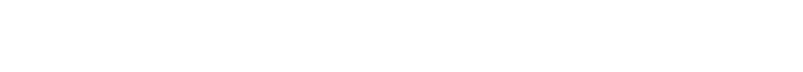

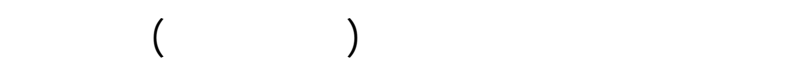

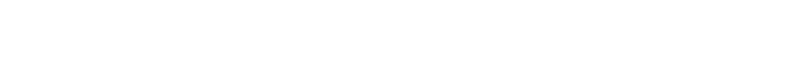

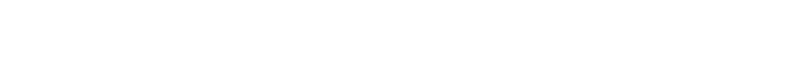

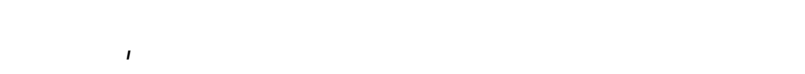

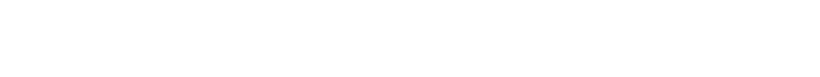

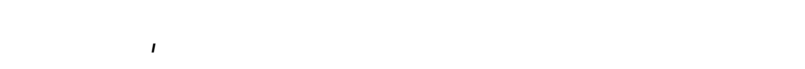

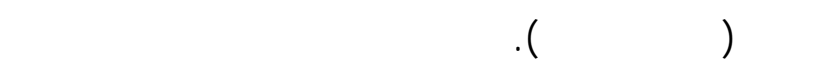
مشلكل التمية الزراعية فى مصر. وحت لا تتعرض مصر لصعوبة توفير الزيوت النباتية

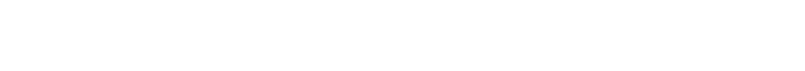

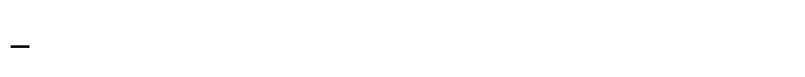

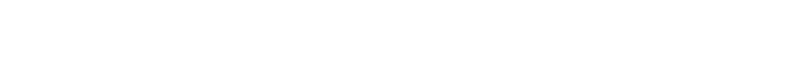

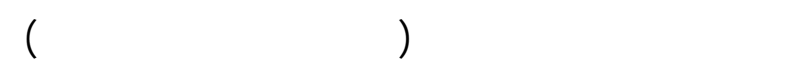

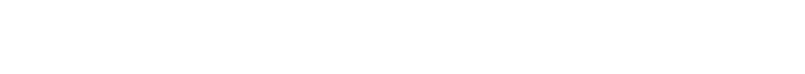

الدهنية الأسلسية اللازمة لجم الإنسان والت مى لاي سطبع

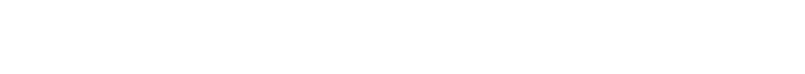

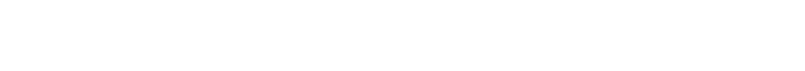

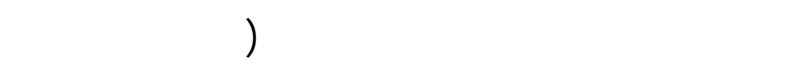

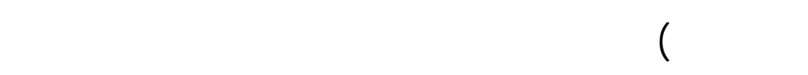

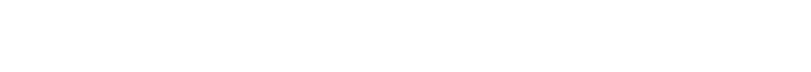

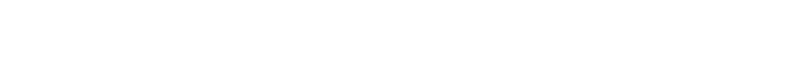
صناعة الأعلاف المركزة، والصابون والمظفلت الصناعية، والبويت (العميرى ولخرون، 7 - . r، ص حساع). وبارغم من أن مصر تمتك أغلب المقومكت المنلخي ـة

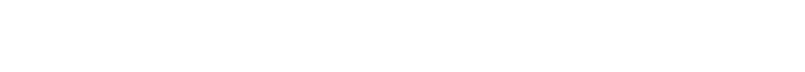

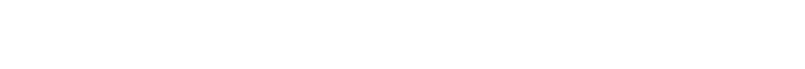

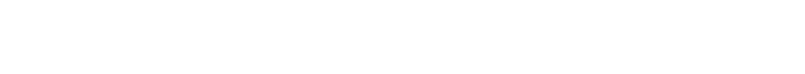

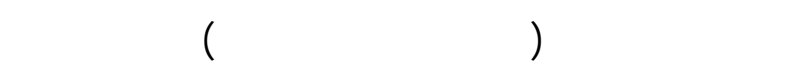

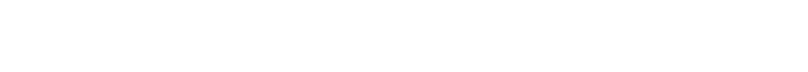

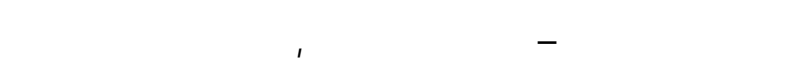

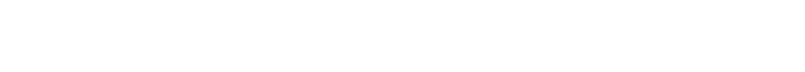
الفترة نحو r مليون طن، وبذك بلك بلغت حهم الفجوة الغذائية

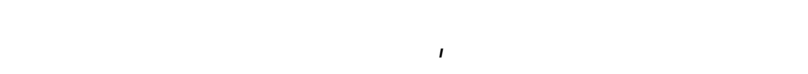

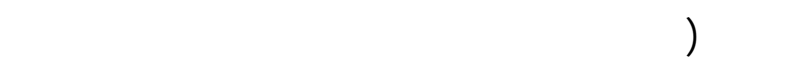

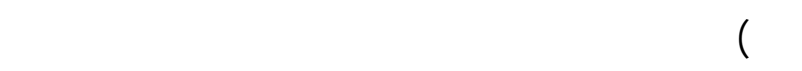

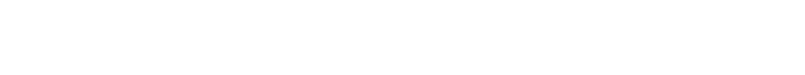
الزيوت النباتية المستورة زيت زهرة للثهس، وزيت فول المبتيراد

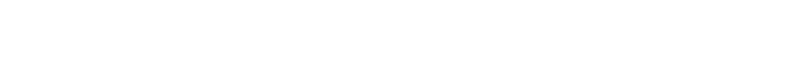

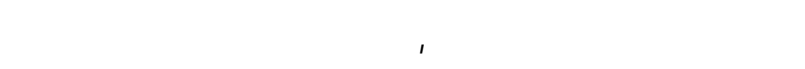

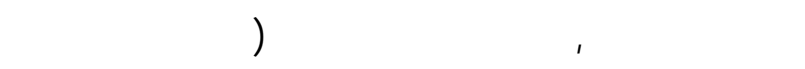

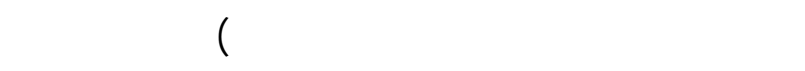

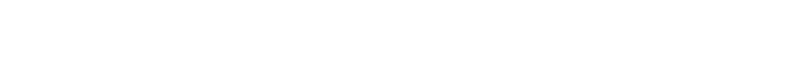

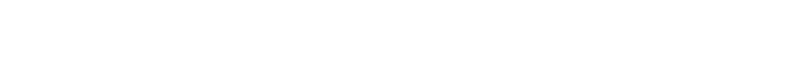

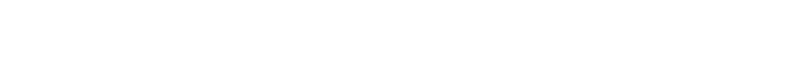

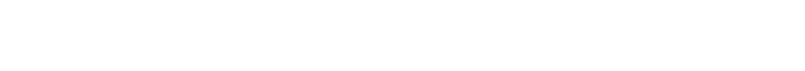


العناية بالصرف، وكذا زراعته فى لخثر من عروة، وأيضاً

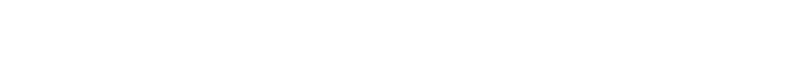

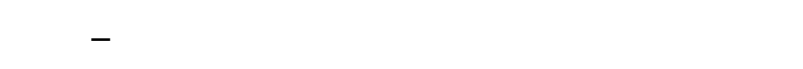

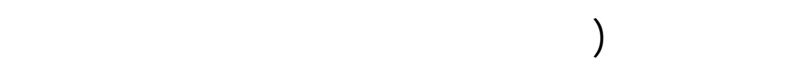

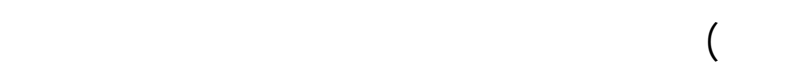

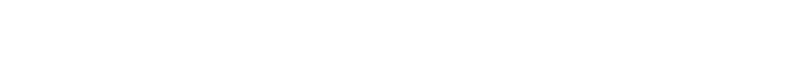

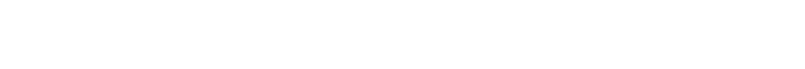

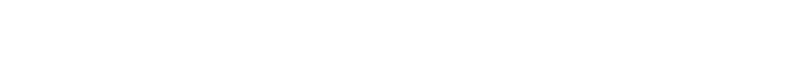

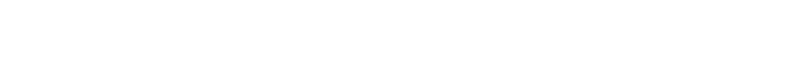

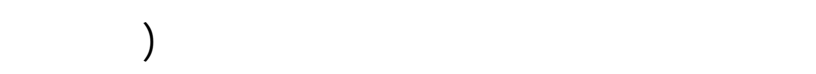

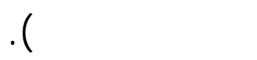

وقد بلغت المسلحة المذزرعة بمحصول زهرة الـ شهص

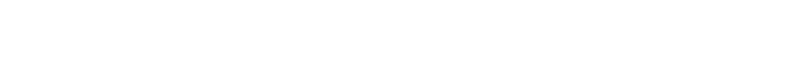

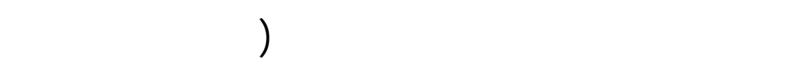

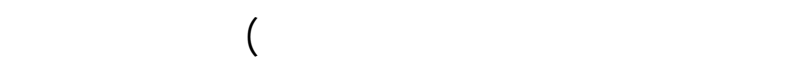

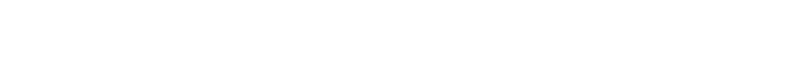

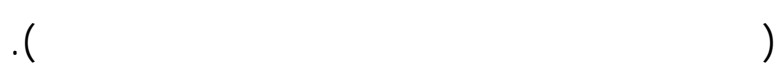

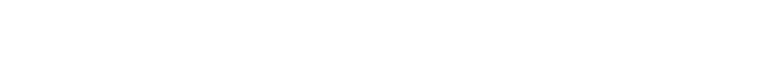

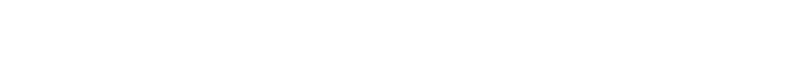

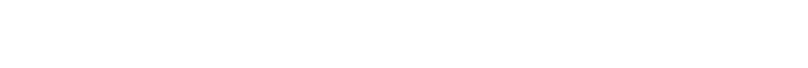

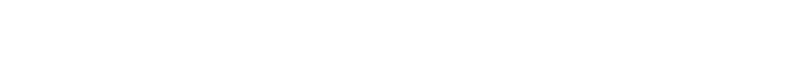

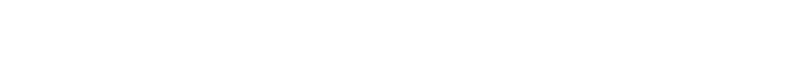

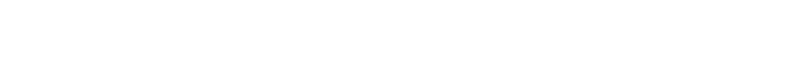

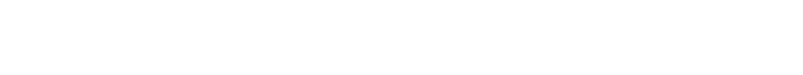

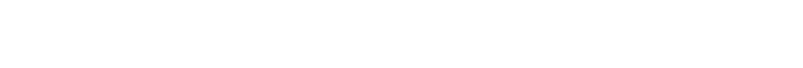

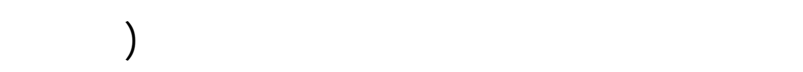

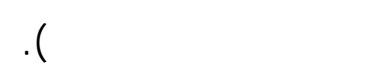

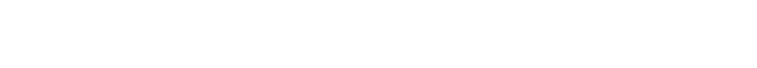

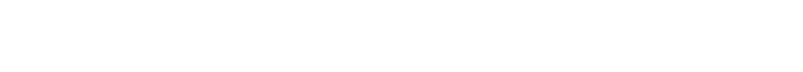

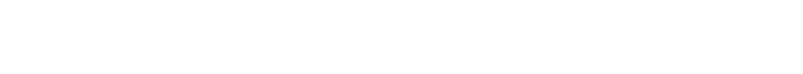

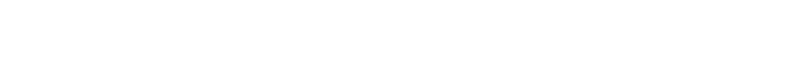

ووضع الخطط والضوابط للوصول لهذا الهذف من خ لاعل

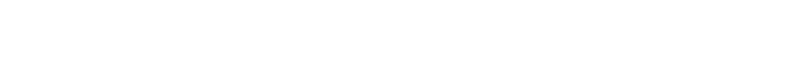

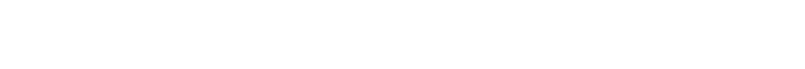

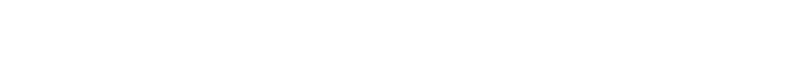

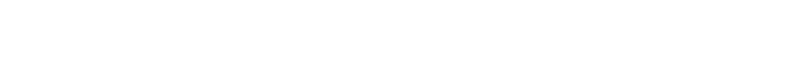

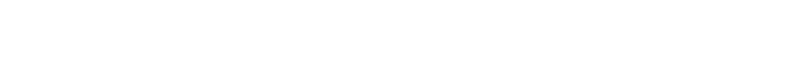

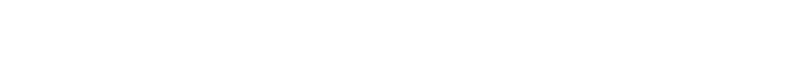
تحملها للجفلف والملوحة، وأيضاً لإرتفاع محتوى بـ ذورها

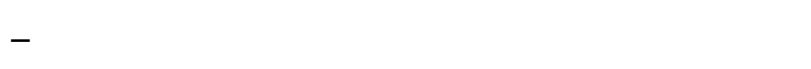

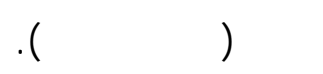

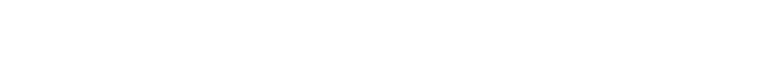
العالمية وإنعكلساتها على المستوى المحل مى قلم ـت وزارة

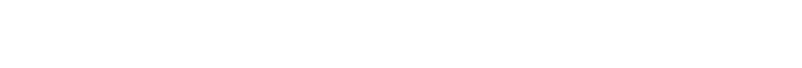

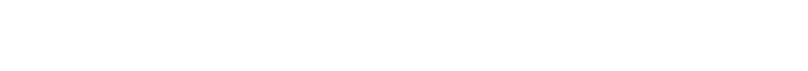

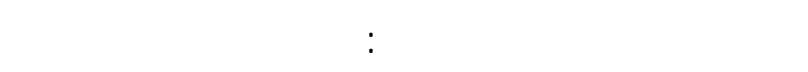

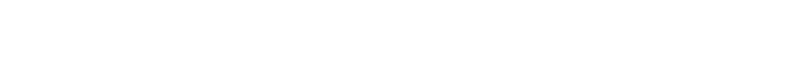

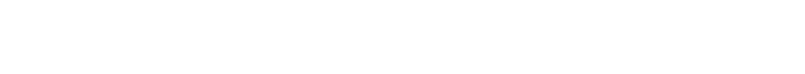

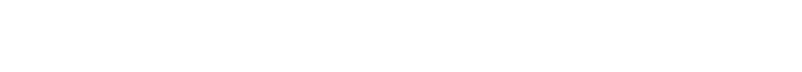

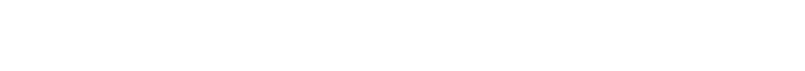

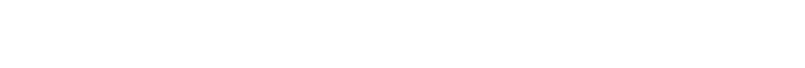

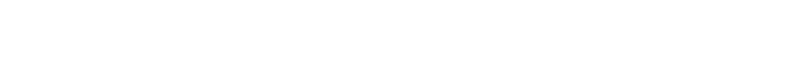

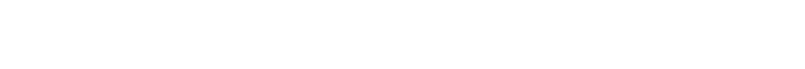

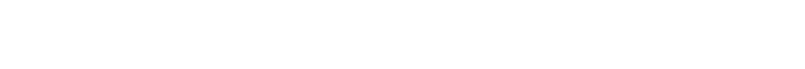

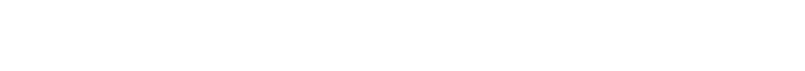

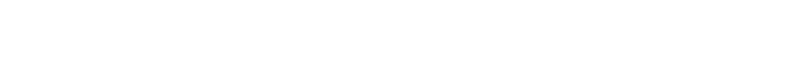

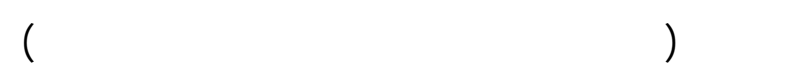

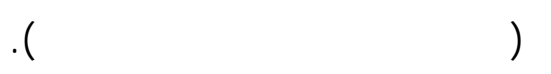

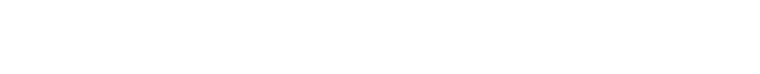

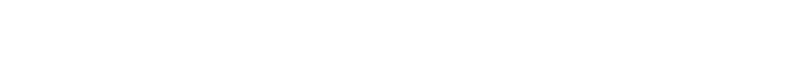

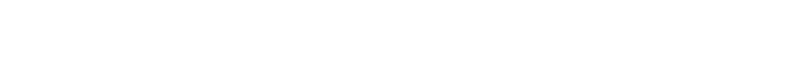

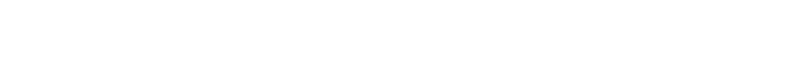


حيث يساعد المسئولين عن العل الإشش ادى ف م وض ع ع

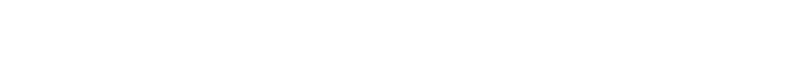

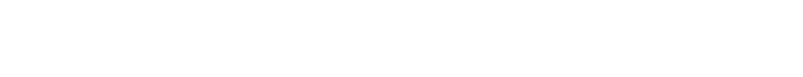

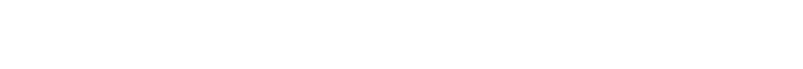

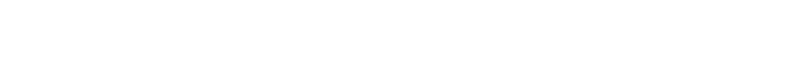

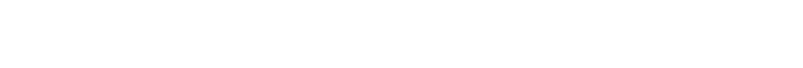

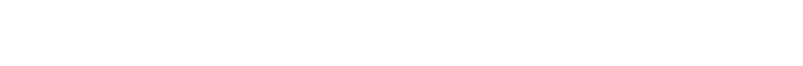
النباتية فى مصر.

\section{لالارقة البحثية}

تشتهل الطريقة البحثية على المجل الجغرافى، والمجل

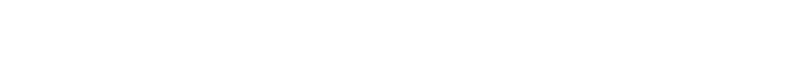
للمتغيرات البحثية الوارة بالبهث وكثية قيلس ـها، وأدوات البيات التحليل الإحصائى.

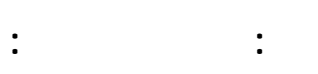

لجرى هذا البحث فى مركزى أبو الطلمير وكفر الدوار

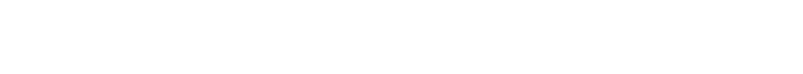
محصول زهرة المثه الزيق، وبنفس المعيار مُ إختي ار

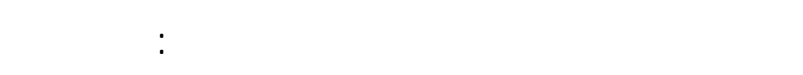

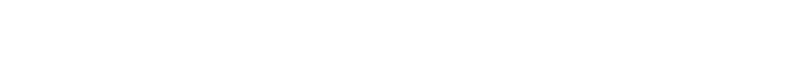
بمركز كفر الدوار.

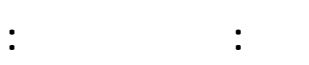

تمثلتشلملة هذا البحث فى جمبع زراع محصول زهرة

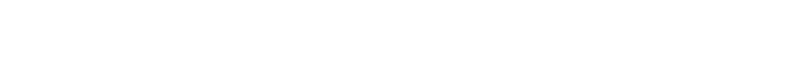

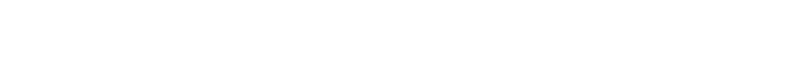

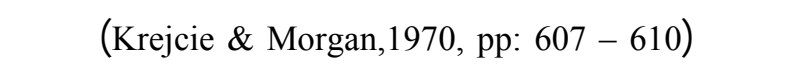

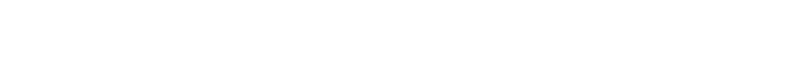

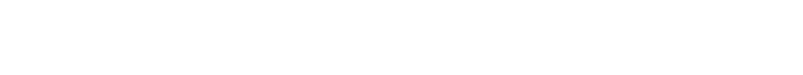
كشوف الحصر لمحصول زهرة الثنه الزيت والموجوة

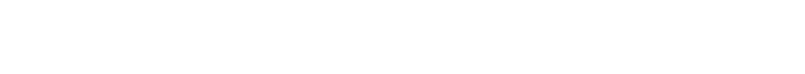

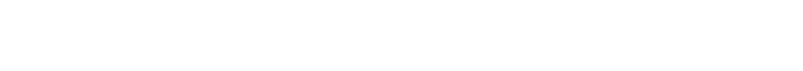
موضح بجدول( (1).
توفر المقوملت المشجعة على التوسع ف ف زراء ـة هـ ذا المحصول بالمحلظة بالقدر الكالف بما لا يتنلسب مع أهميته فـ الإقتصاد القوم المصرى.

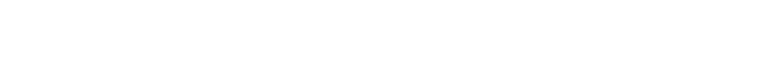

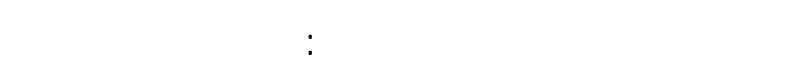
المقوملت المشجعة على التوسع فى زراعة محصول زهرة الإنس

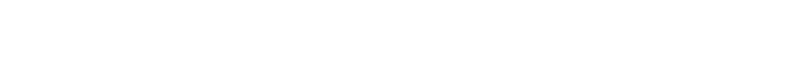

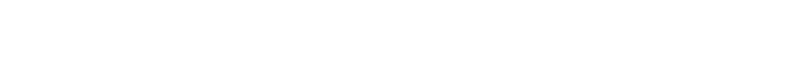
المحصول من وجهة ظر ره؟، وما هي مصادر المعلوملت

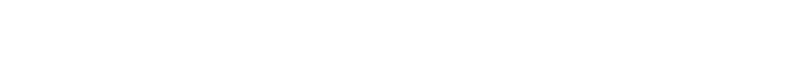

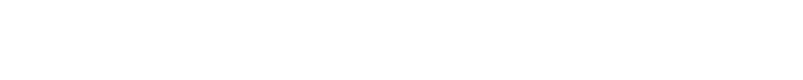

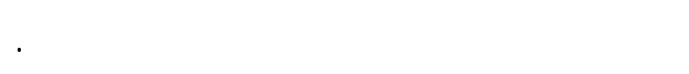

\section{لأه لـ أله}

إتنساة مع مشكلة البحث المشار إليها آفَاَ لمكن صياغة الأهداف التالية:

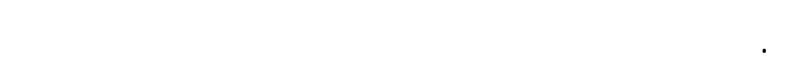

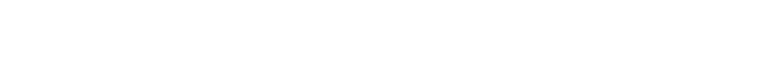
المبحوثن.

r. تحديد درجة توفر المقوملت المشجعة على التوسع ف قى

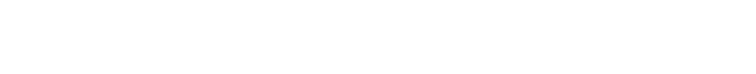
المبحوثين.

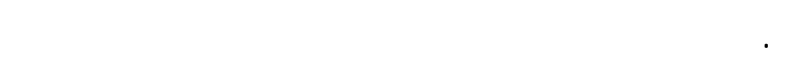

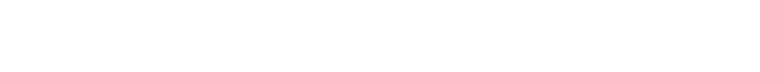
الزيق. ع. التعرف على المعوقلت الت تولج هـ المبح -وثين عن ـد

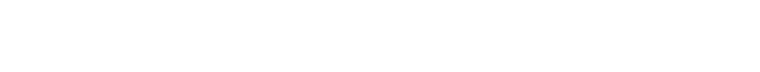

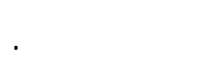
الأهمية الفلبقة للبهث:

تكمن الأهمية الظبيقية لهذا البحث كونه لحد الإبهلملت

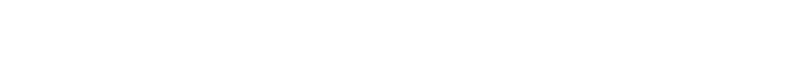


جرط ا ـ توزيعشاملة البهث وعينته عل الفرى موضع الدرلسة.

\begin{tabular}{cccccc}
\hline اللمركئ المختارة \\
\hline
\end{tabular}

المصدر: الإدارة الزراعية بمركزى أبو الطلمير، وكفر الدوار - مديرية الزراعة بمحلظة البحيرة، 10 ـ اعل

المقوملت الإنتلجية وتتضمن عثرة مقوم ـات، ومجموء $ة$

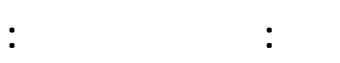
المقوملت الإشش الية وت شتمل عل مع ثماني ـة مقوم لت، ومجموعة المقوملت الإقتصاية وتحتوى علىستة مقوملت، ومجموعة المقوملت التسوقية وتتمل فى ثلاثة عثربمقوماً.

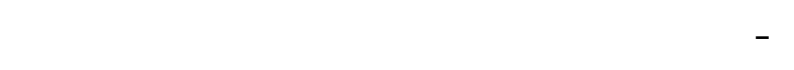

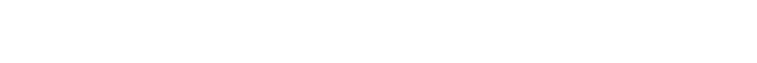
المبحوثن: وقصصد بها مدى إعقاد المبح ـوث لأهمي ـة

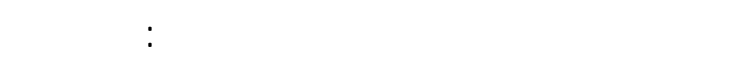

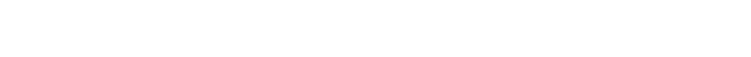
الزوسع فى زراعة محصول زهرة اللشهس الزيقى مـ ن

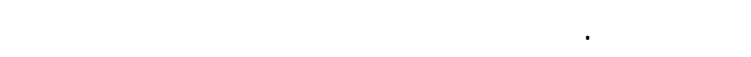

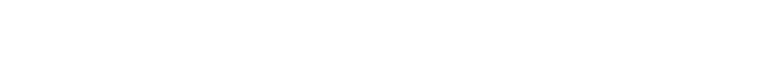

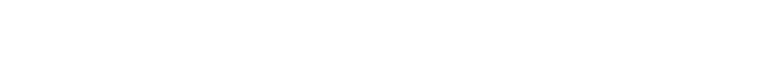

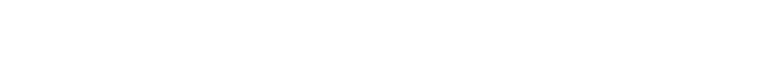

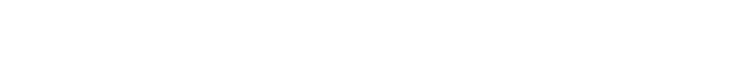

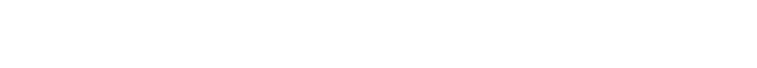
الترتيب، وبذك ترواح المدى الظرى للكل من مجموعة

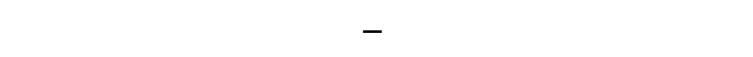

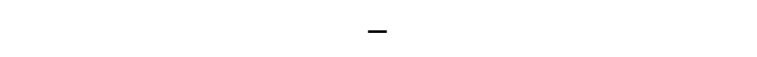

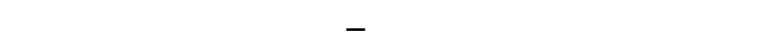

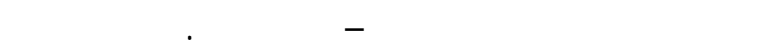
على المتوبط المسابع لأهمية كل مقوم من مقوملت لكل

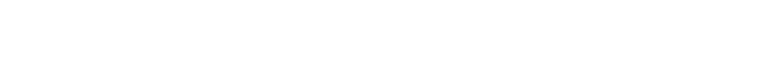
الفئت الثلاثة فى الأوزلن المقابلة لها، فم جمعت مع آَأ

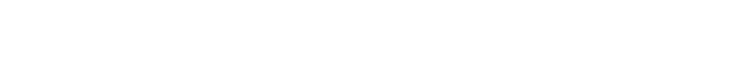

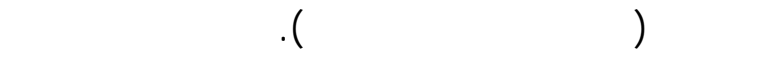

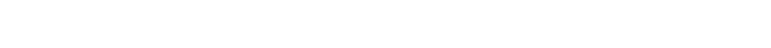
بالمقابلة اللشخ صية للمبح ـوثين، والت عسد ـق إع إع دادها

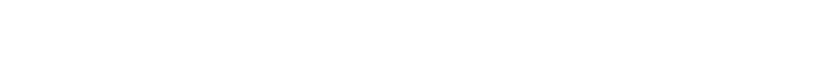

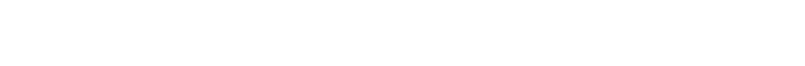

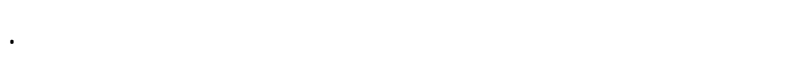

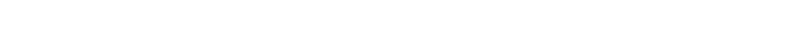

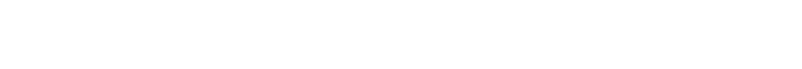

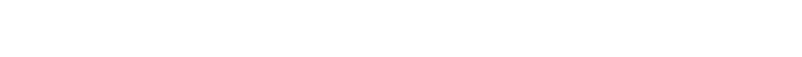

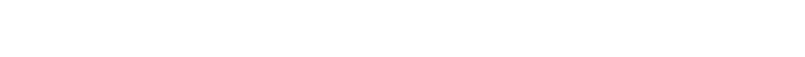

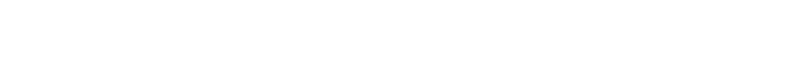

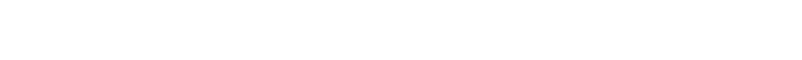

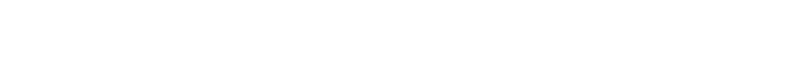

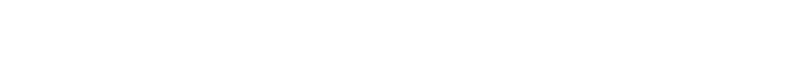

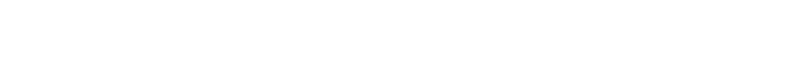
محصول زهرة اللثهس الزيق من وجهة ظرهئ.

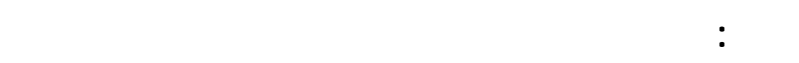

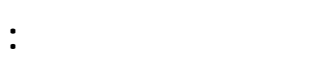

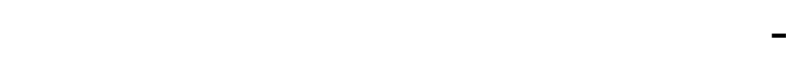
زهرة اللثهس الزبق: ويقصد بها المحفزات القى منشأنها

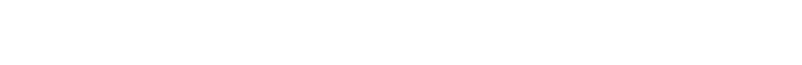

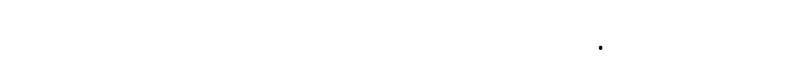

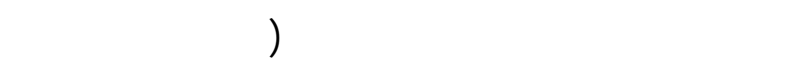

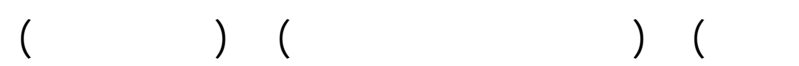

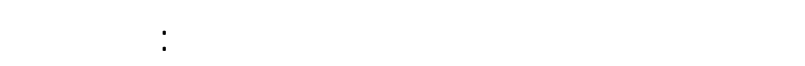


خالماً: ألولت النحلل؛ الإحصائ:

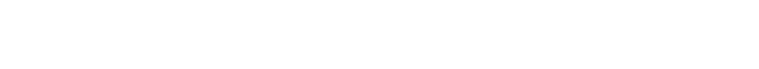

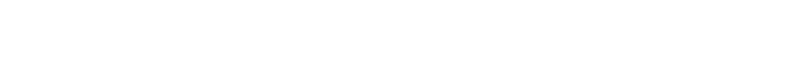
النسب فى تحليل البيانت وعرض الإح النتائج.

\section{النتائج ومنالشتنها}

أولاًا: رجة ألهمية وتوفر مجموعة المقوم الت الإنتاجي ة

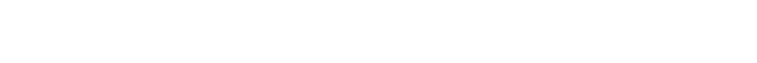

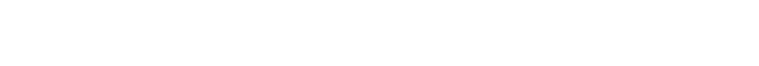
ما يلى: 1 -ررجة أهمية مجموعة الفوملت الإنتاجي a الم عشجعة عل التوسع ف زراعة محصط زهرة اللشس الزيق الزبن من وجهة ظلر المبحوثن:

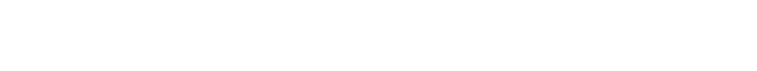

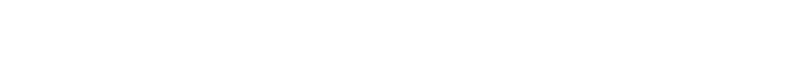

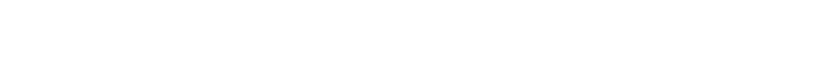

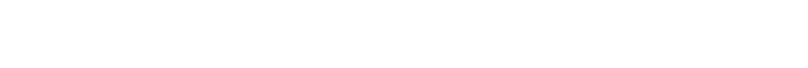

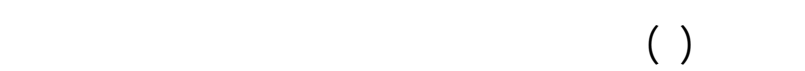

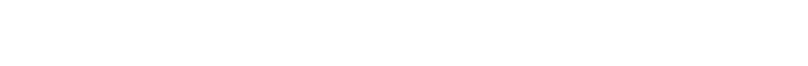

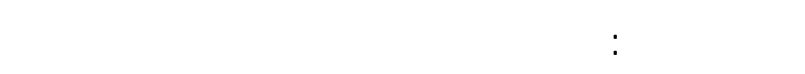

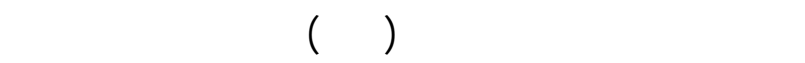

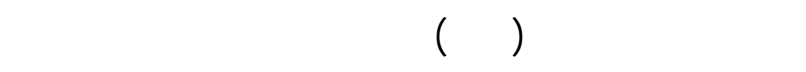

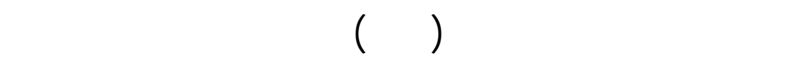

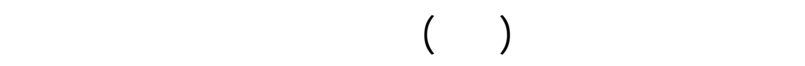

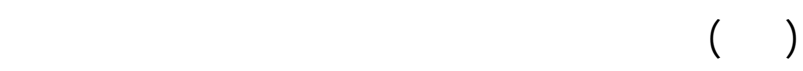

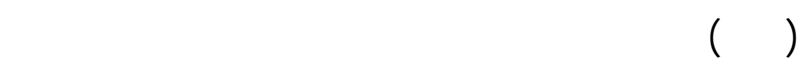

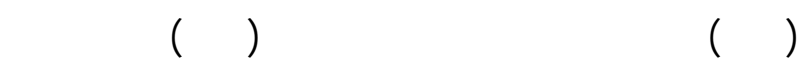

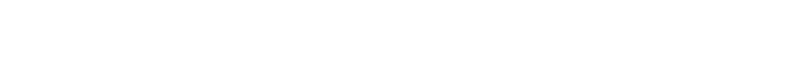

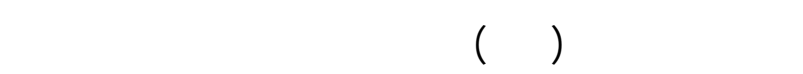

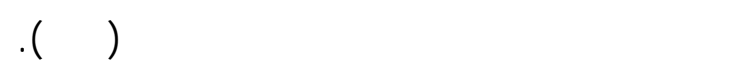

المتوبط النسب لأهمية كل مقوم مـ ن مقوم لت كـ لل

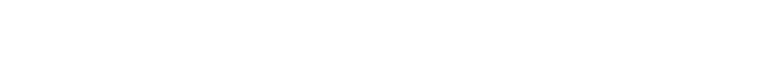

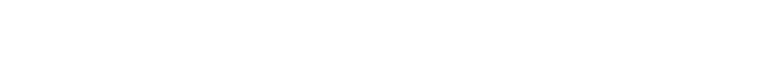
ف ..1.

r -رجة توفر المقوملت المشجعة عل التوسع ف زراعة

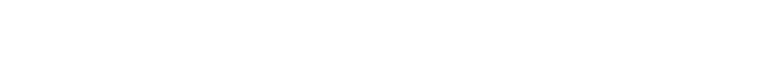

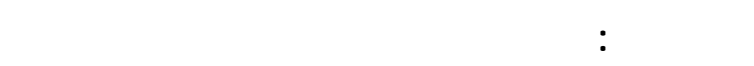

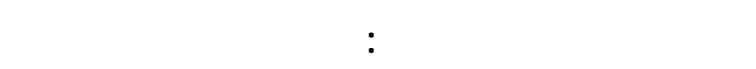

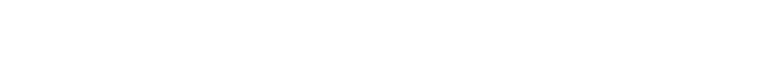

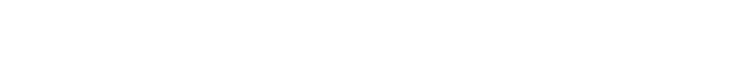

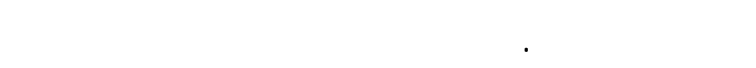

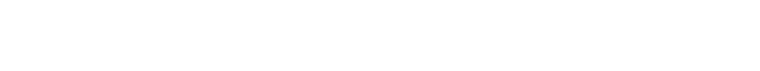

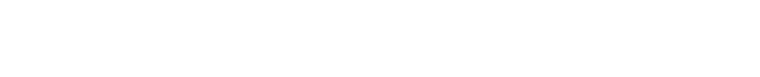

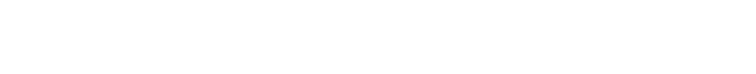

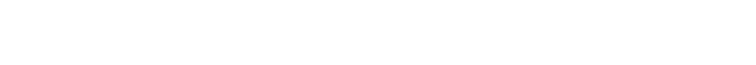

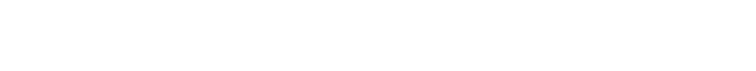

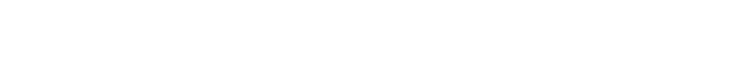

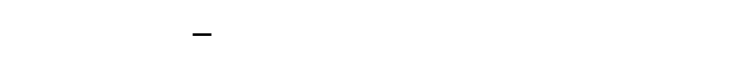

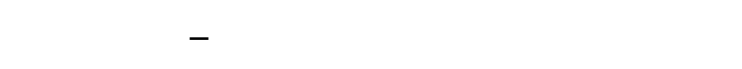

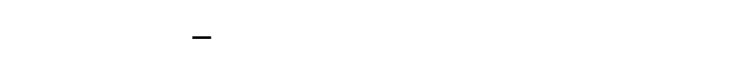

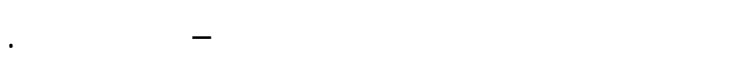

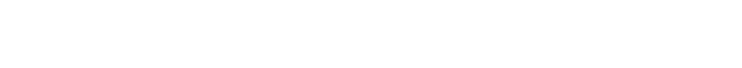

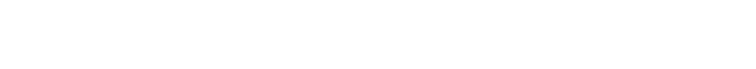

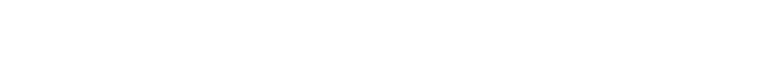

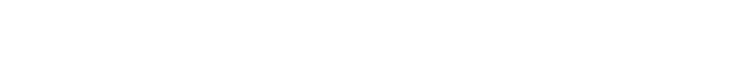

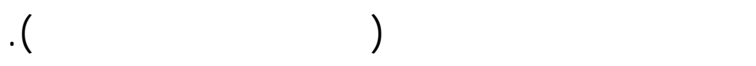

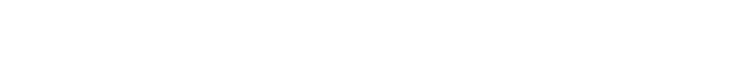

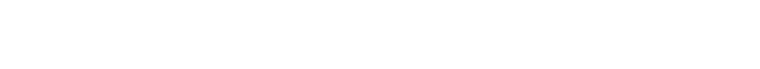

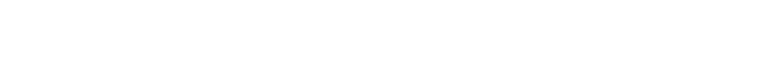

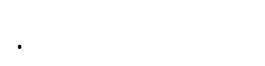




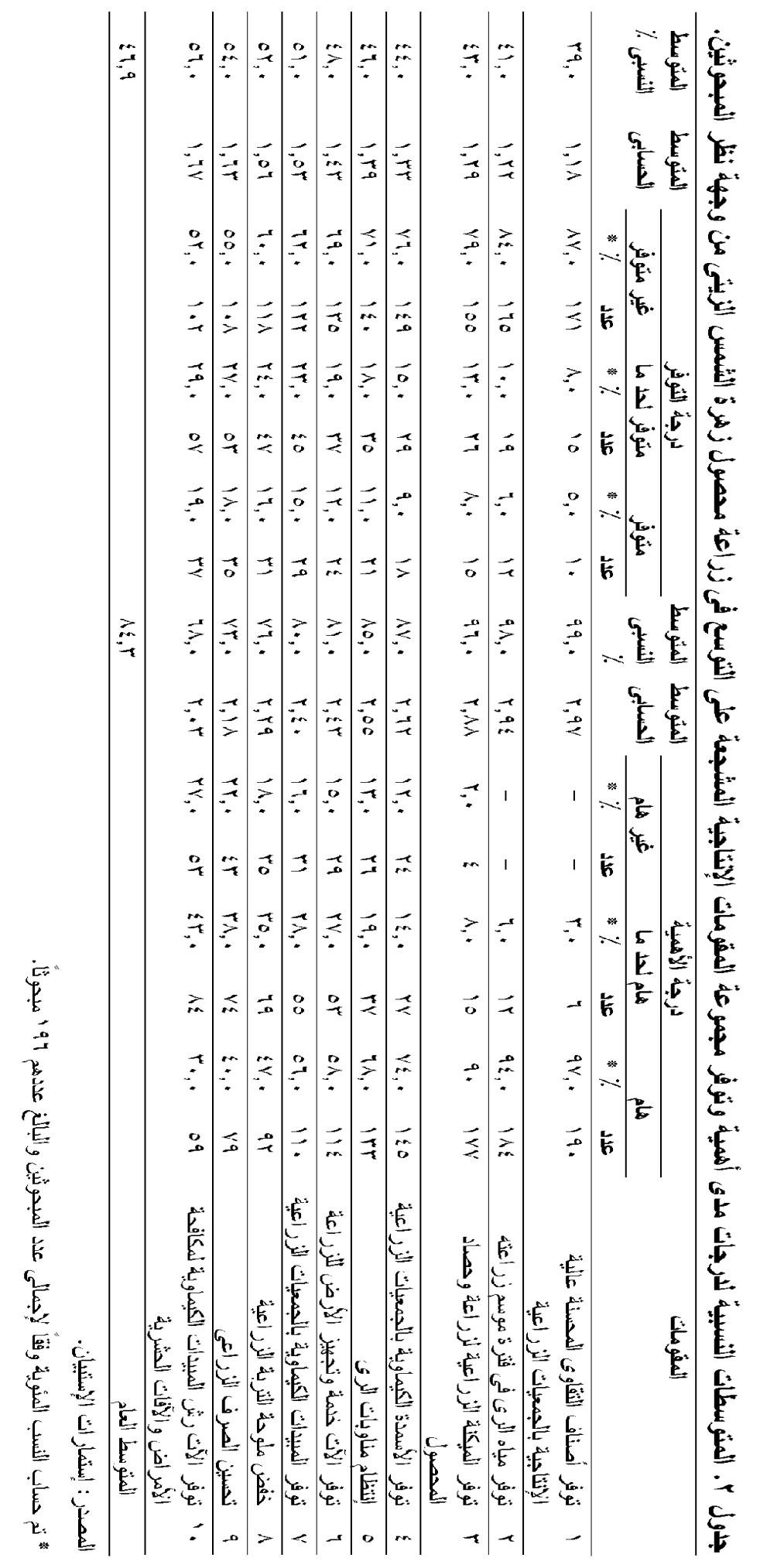


r -رجة توفرمجموعة المقوملت الإنتاجية المشجعة عل التوسع ف زراعة محصط زهرة اللشعس الزيق مـ ن وجهة ظار المبحوثن: للاوقوف على مدى توفر كل مقوم من مجموعة المقومك

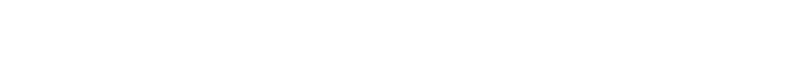

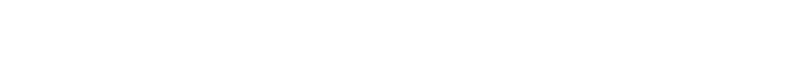

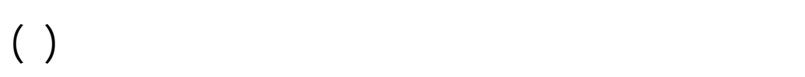

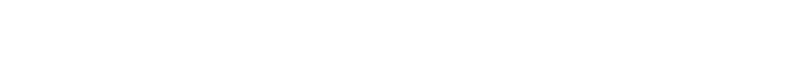

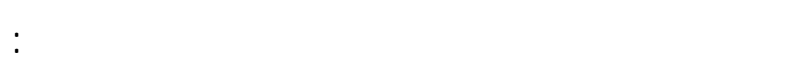

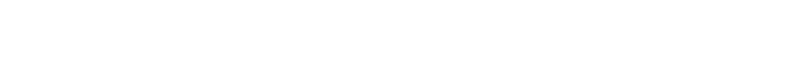

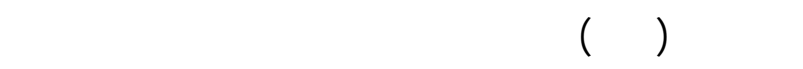

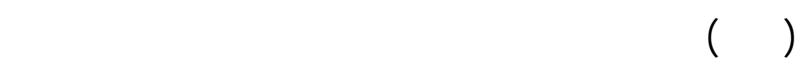

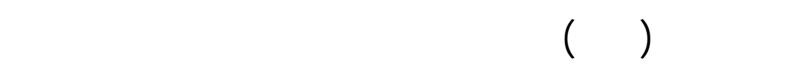

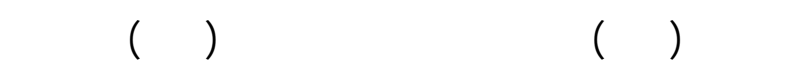

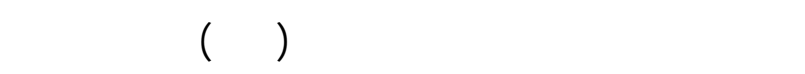

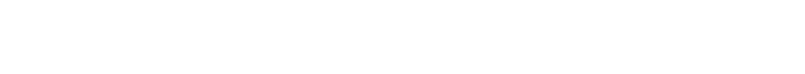

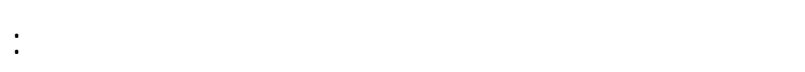

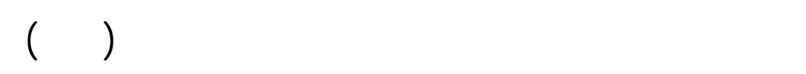

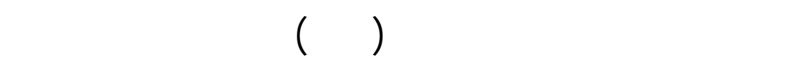

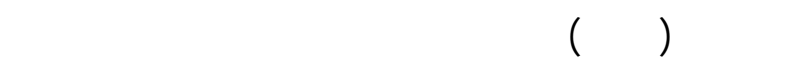

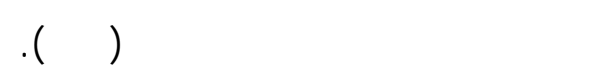

ويتبين من هذه النتائج أن ثمانية من مجموعة المقومات

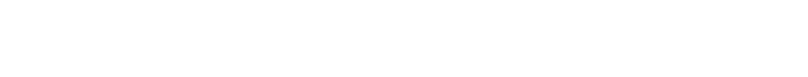

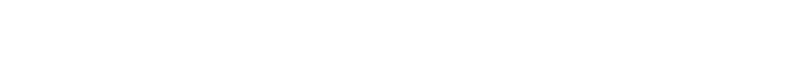

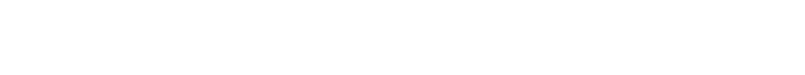

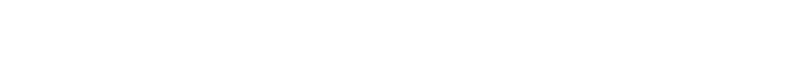

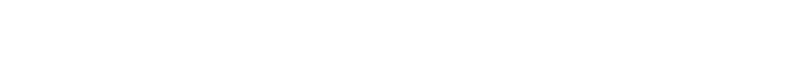

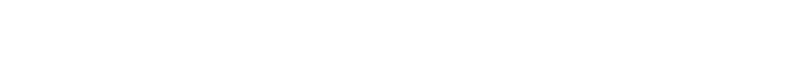
إنتلجية هذا المحصول.

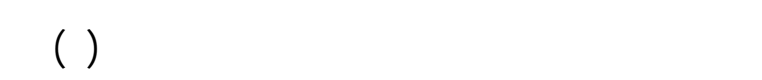

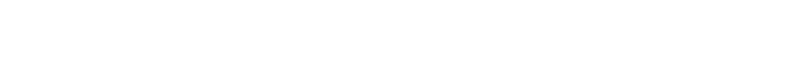

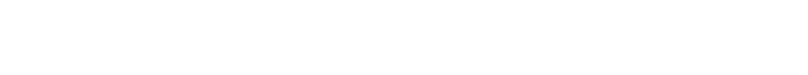

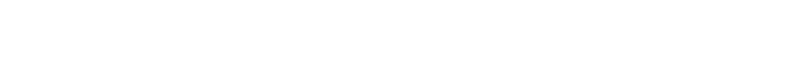

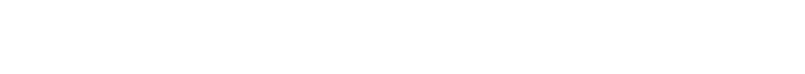

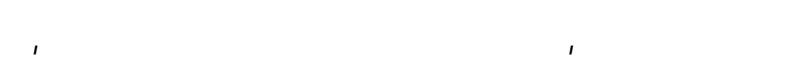

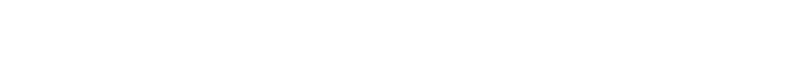

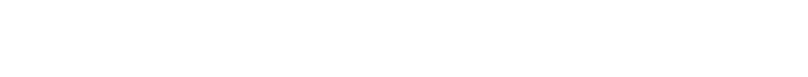

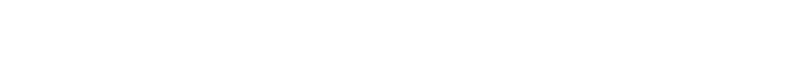

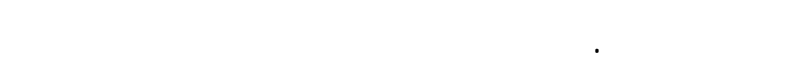

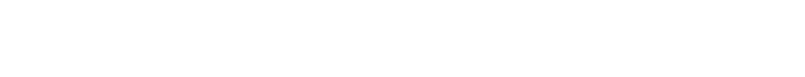
لحدما فـ تشجيعهر على التوسع فى زراعة هذا المحصول.

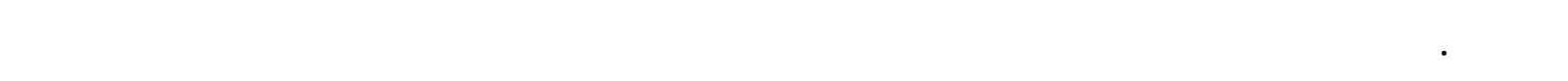

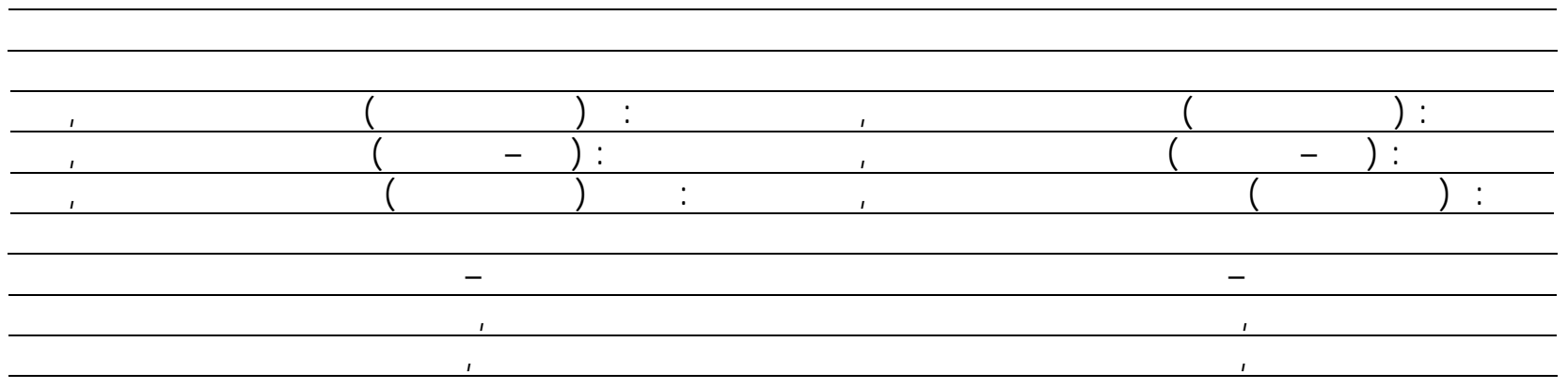


يمكن تشجبع الزراع عل م التوس ع ف ف زراء ــة هـ ذذا المحصول.

ثلنياً - رجة ألمية وتوفرمجموعة الفقومات الإشد الية المشجعة على التوسع ف زراء مة مح صرل زهـ ـرة الثش الزبقدن وجهة قار المبحوثن: 1 - درجة أهمية مجموعة الفوملت الإرشالية الم ششجمة على التوسع ف زراعة محصط زهرة الثشس الزبق من وجهة قالر المبحوثين:

بليستعراض مدى أهمية كل مقوم من مجموعة المقوملت الإششادية المشجعة على التوسع فى زراعة محصول زهرة

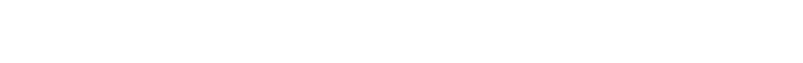

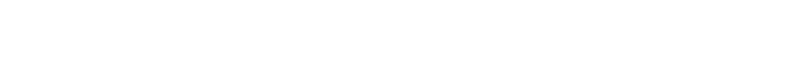

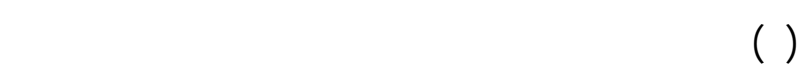

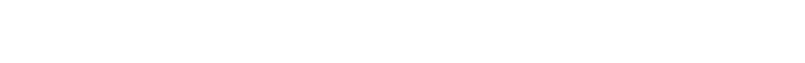

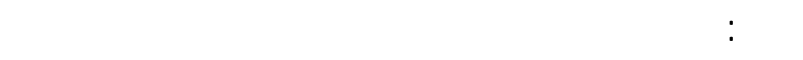

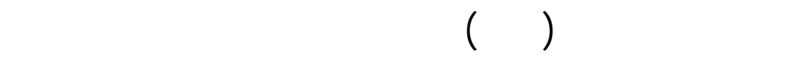

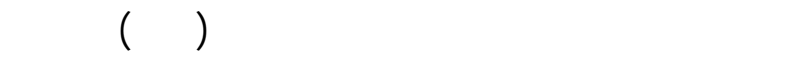
حقول إششادية لمشاهة ومتابعة مرلل عملي الت زراء وإنتاج المحصول على الطبيعة (97٪)، وت ـوفر الذ شررت

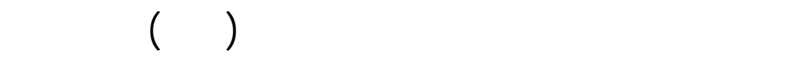

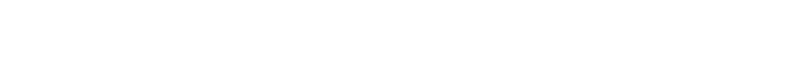

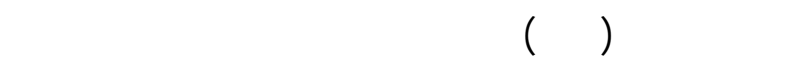

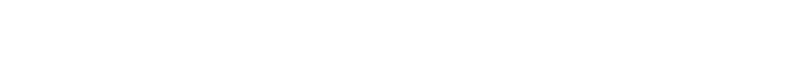

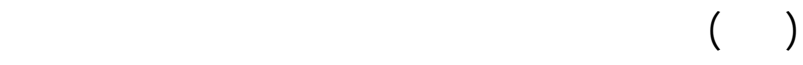

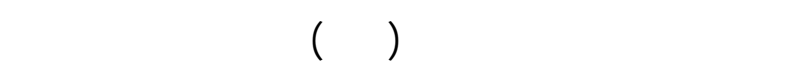

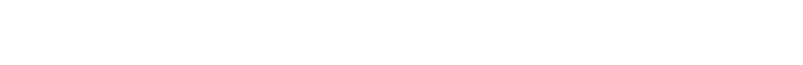

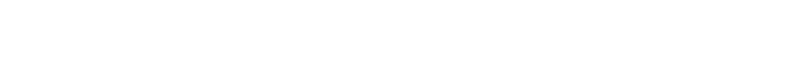
متوسطة وبمتوطط نسب قدره (VY\%).
ويتضح من تلك النتائج أنستة من مجموعة المقوم لت الإنتلجية جاءت درجلت توفره ا منخف مضة ف مى ت شجبع المبحوثن على التوسع فى زراعة محصول زهرة ال شهص

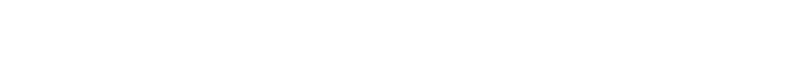

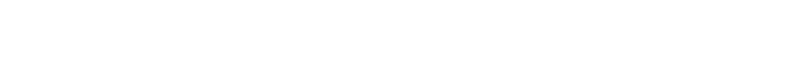

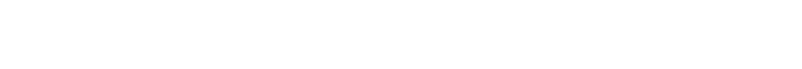

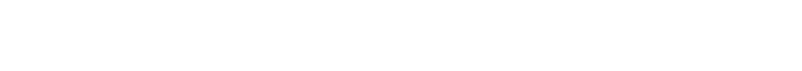
متوسطة. كما أشارت النتائج البحثية الوارة بالجدول(س) إلى أن

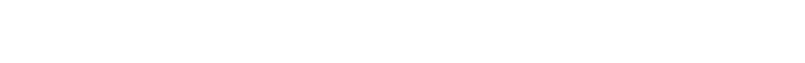
الإنتلجية المشجعة على التوسع فى زراعة محصول زه -رة

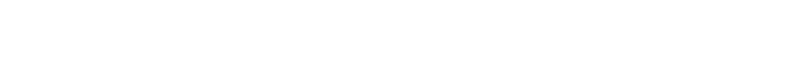

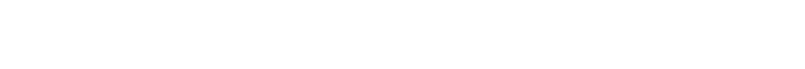

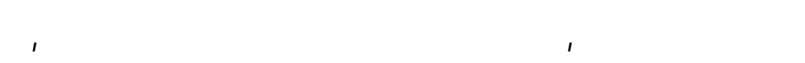

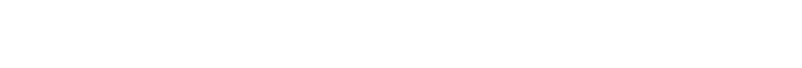

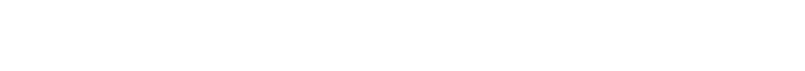

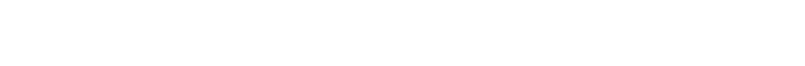

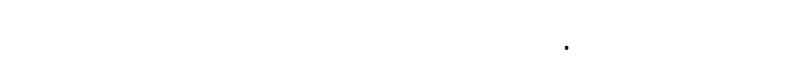

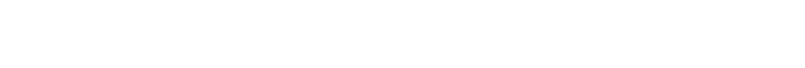

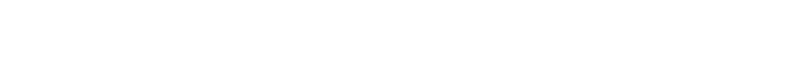
زراعة هذا المحصول.. ويستخلص مماسبق أن المتوسط النسب العلم لأهمي ـة

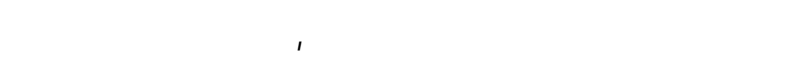

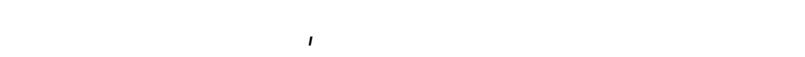

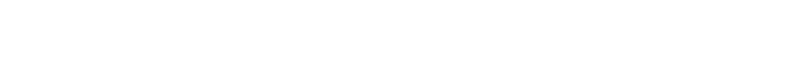

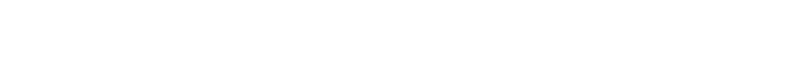
زراعة محصول زهرة للثهس الزيق، كما لجمع -و عل م.

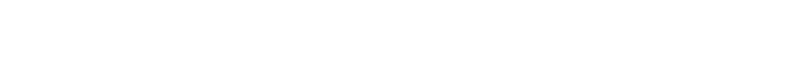

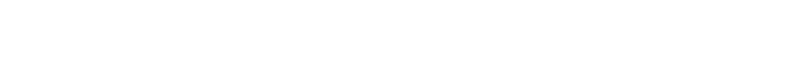
المائية العل على توفر هذه المقوملت بالقدر المنلبب، حتى المبن 


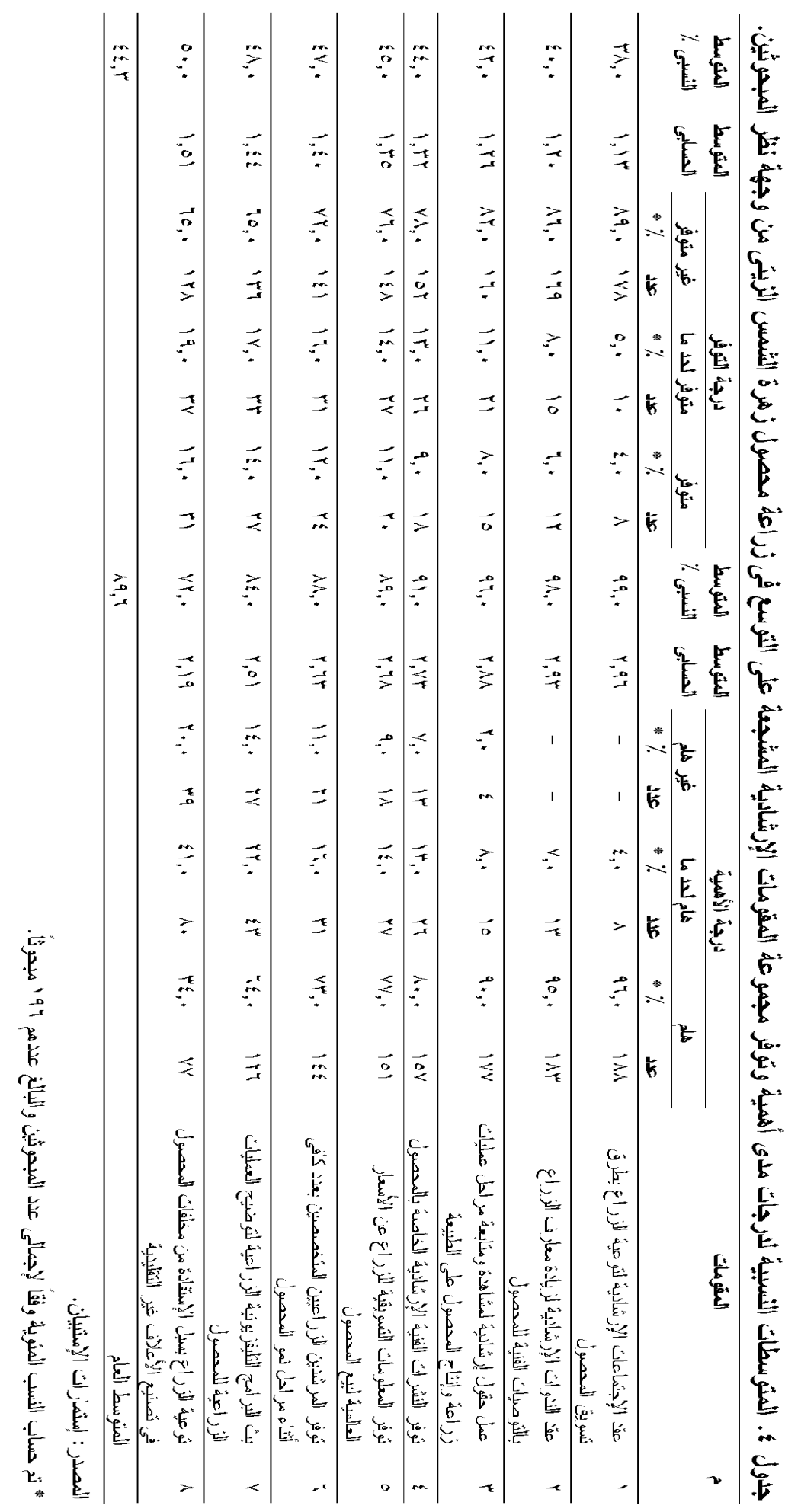


r - درجة ترفرمجموعة المقومات الإيش الية الم شجعة

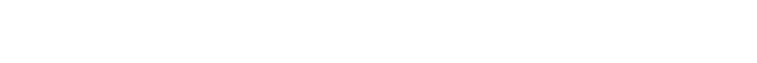
من وجهة ظلر المبحوثن:

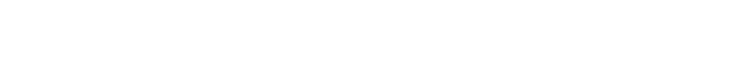
المقوملت الإيشادية المشجعة على التوسع فى زراء

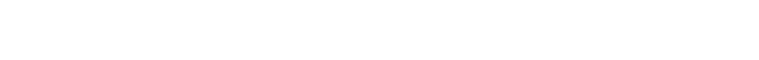

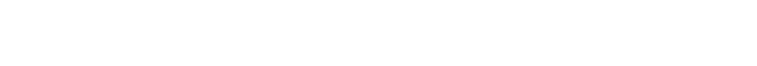

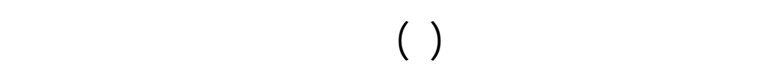

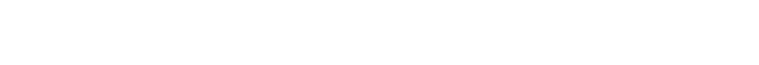

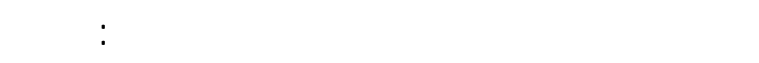

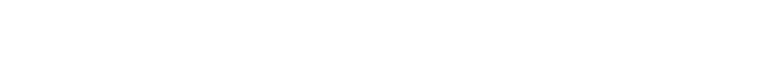

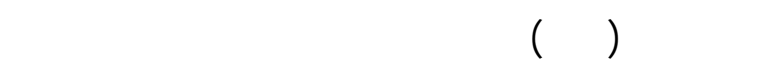

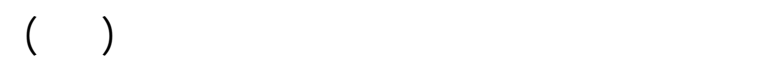

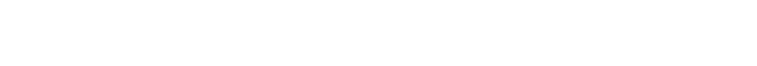

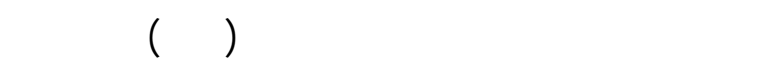

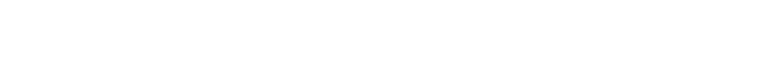

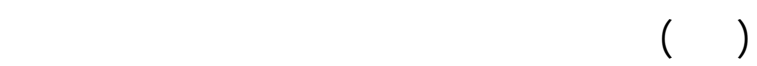

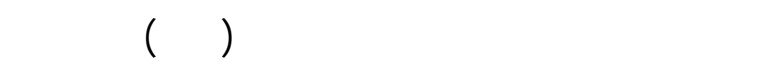

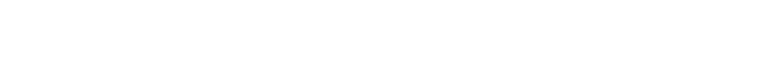

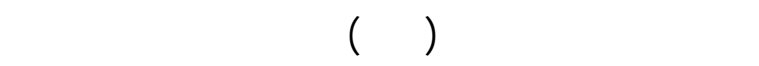

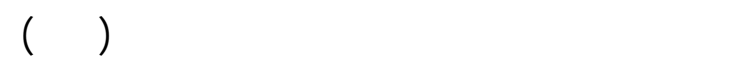

ويتبين من هذه النتائج أنسبعة من مجموعة المقوه لـ الت

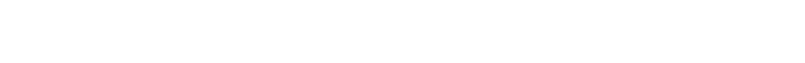

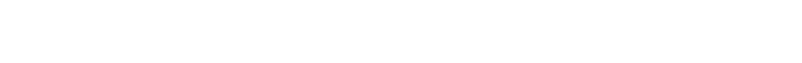

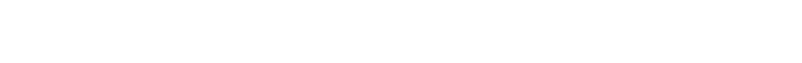

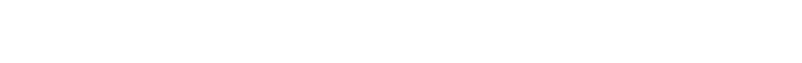

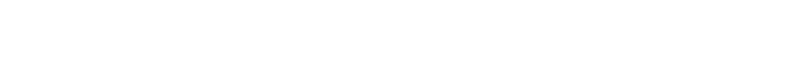

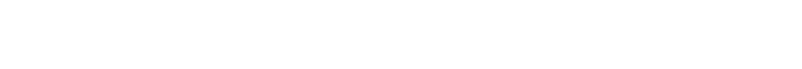

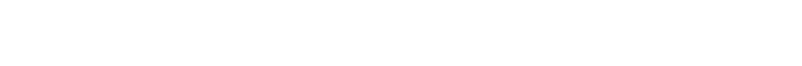

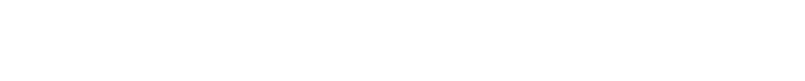

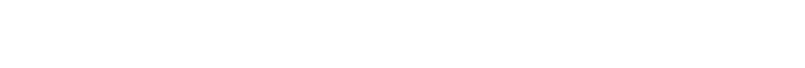
المحصول على الزوسع فى زراعته.

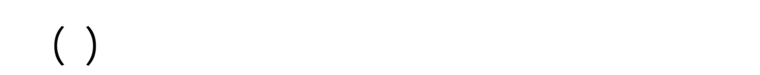

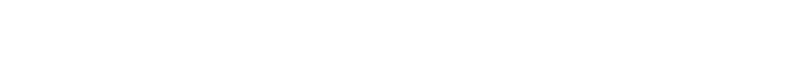

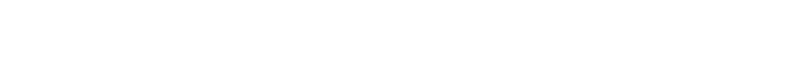

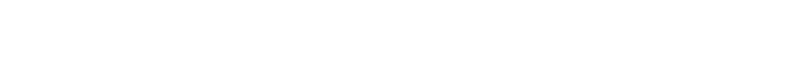

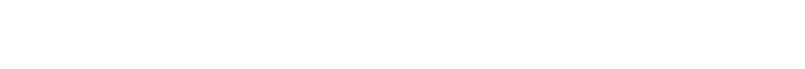

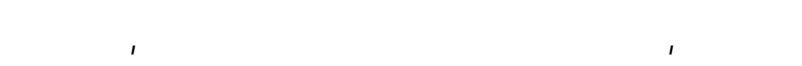

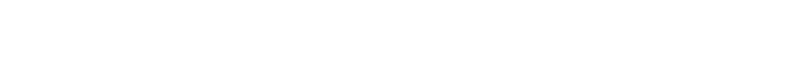

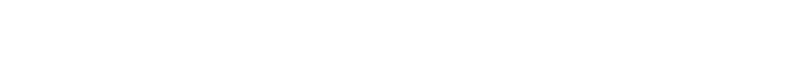

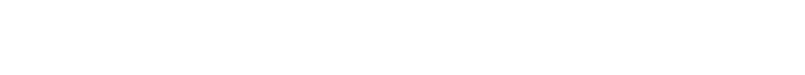

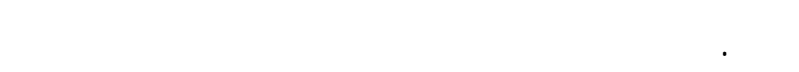

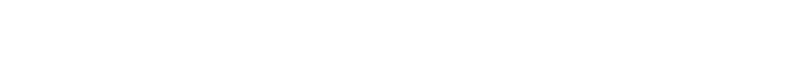
تشتبعهم على التوسع فى زراعة هذا المحصول.

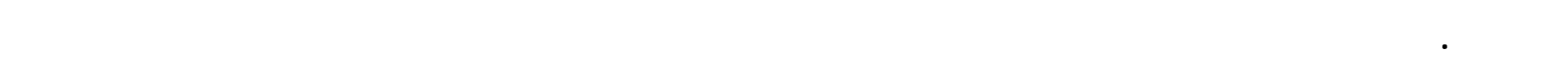

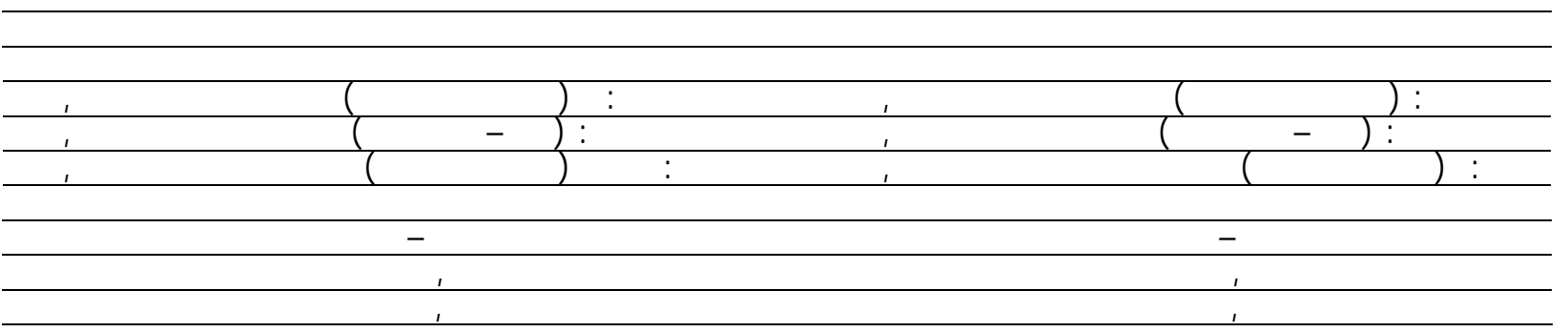


إنخفاض توفر هذه المجموعة، مما يظلب م ن الم سئولين

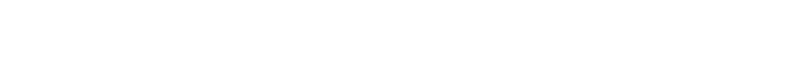

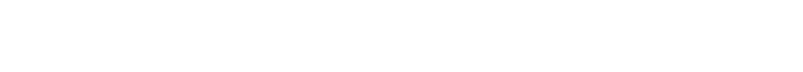
لجل إقناعه على التوسع فى زراعته.

ثالثأ - درجة ألمية وتوفرمجموعة الفقومل الإقت صالية

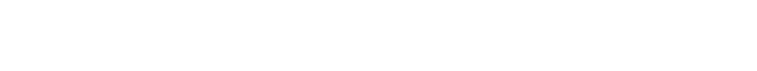
الثشس الزبقدن وجهة ظلر المبحوثين: 1 - درجة لأهمية مجموعة الفوملت لإفتصاية المشجمة عل التوسع ف زراعة محصط زهرة المشس الزبق من وجهة قالر المبحوثن:

للوقوف على مدى أهمية كل مقوم من مجموعة المقوملت

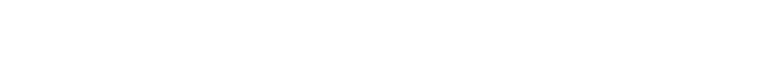

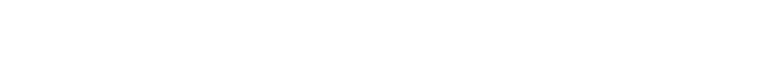

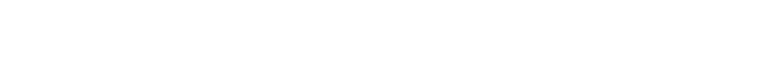

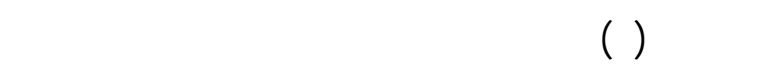
أهميتها مرتقعة حيث ترولهت متوسطاتها النبية ما بين 99٪ وعـ٪ على النحو التالى: توفر الإمكانيت المالية

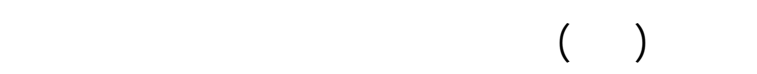

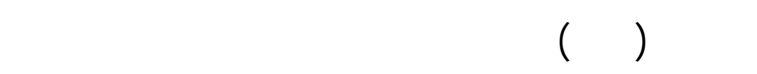

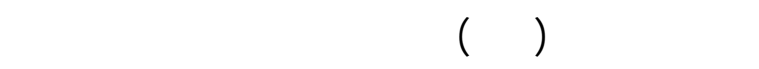

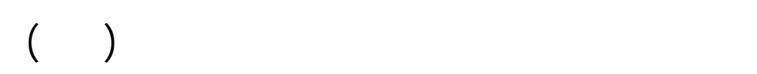
ودعم الدولة تكالف مقاومة الأمراض والآفلت الهشرية

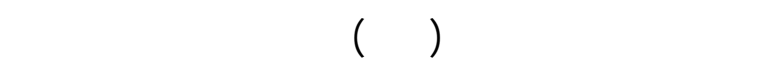

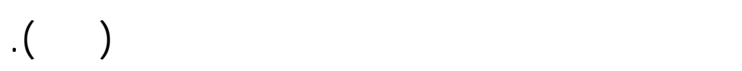

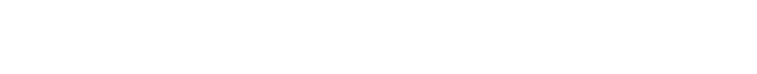

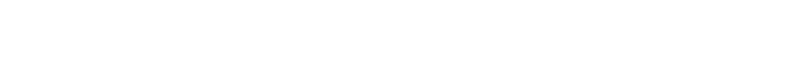

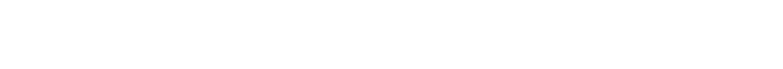

ولخيراً جاعت درجة توفر المقوم الخاص بتوعية الزراع بسل الإستقاة من مخلفلت المحصول فى تصنيع الأعلاف غير القلينية متوسطة وبمتوسط نسب قدر ( . \%٪).

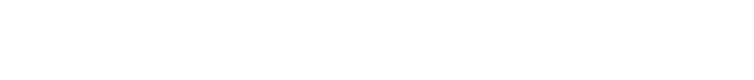
الإبشادية جاءت درجلت توفرها منخف مضة ف ق ت ششجبع

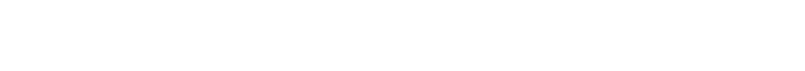

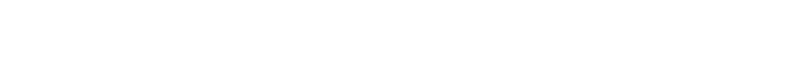

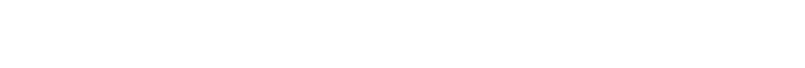
توفير هذه المقوملت، مع ضرورة التركيز على توفر المقوم

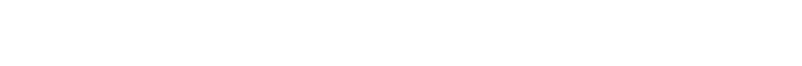

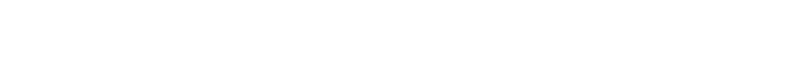
والتى لكدته النتائج أن درجة توفروه كانت متوسطة.

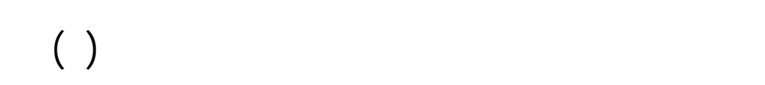

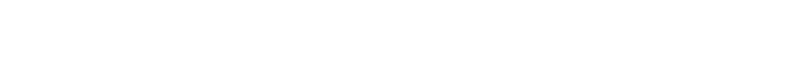

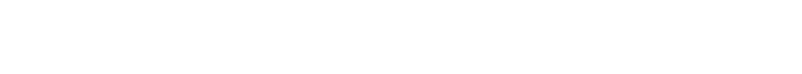

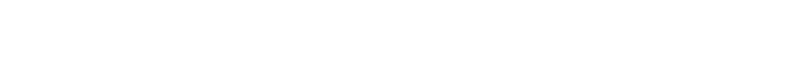

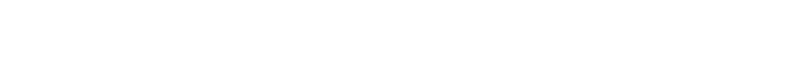

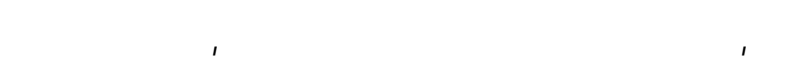

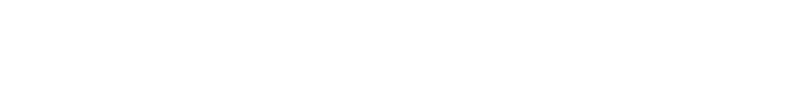

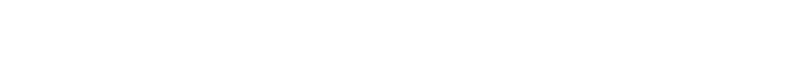

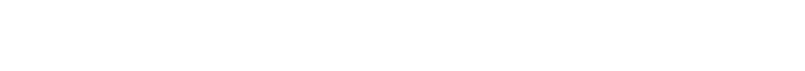

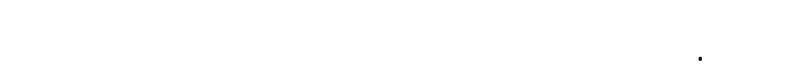

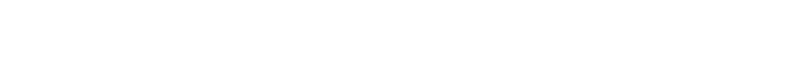
لحد ما فى تشجيعه على التوسع فى زراعة هذا المحصول.

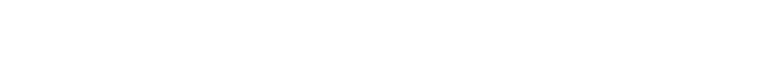

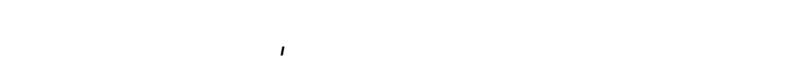

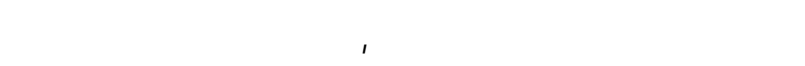

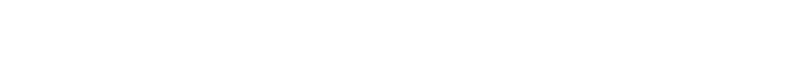

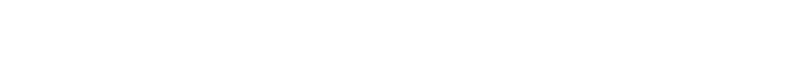

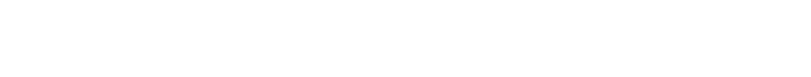




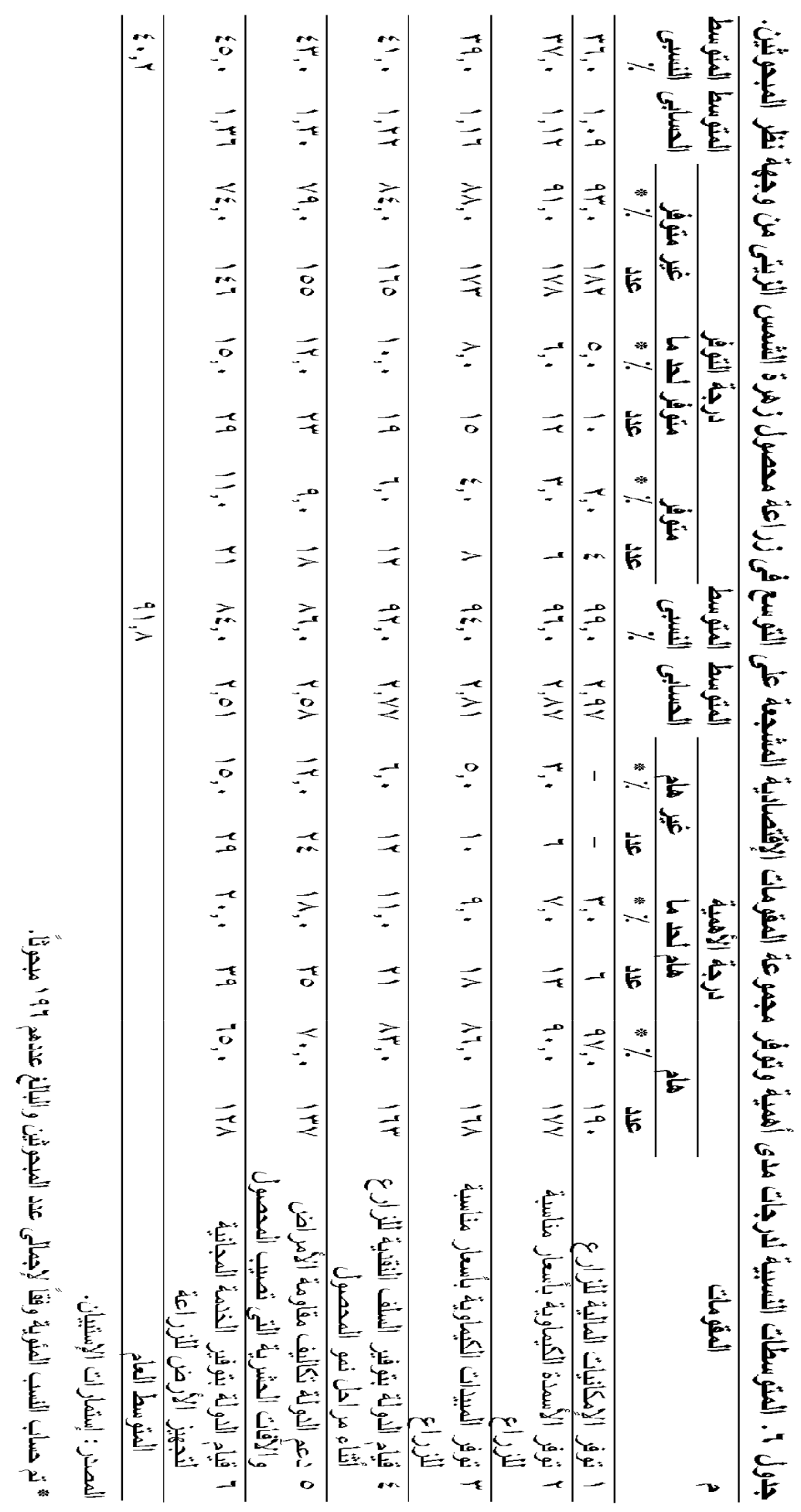


عن أن جمبع تلك المقوملت جاءت درجلت توفرها منخفضة

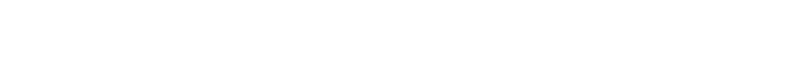

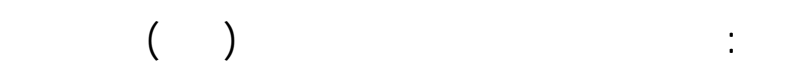

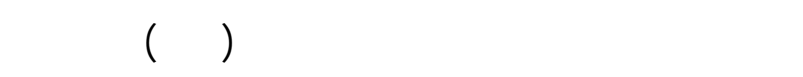

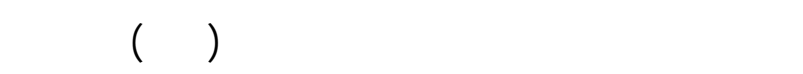

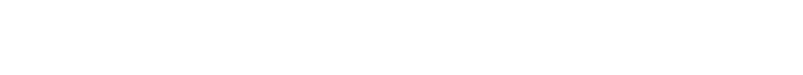

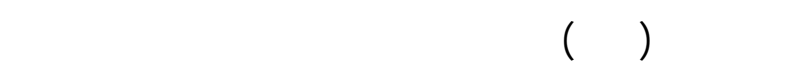

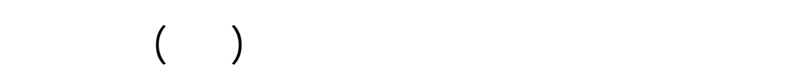

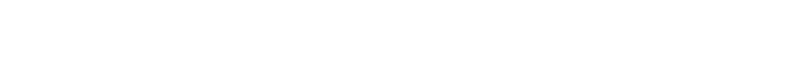

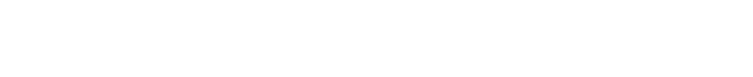
الإقتصادية المشجعة على التوسع فى زراعة محصول زهرة

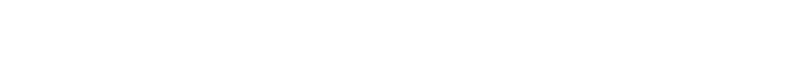

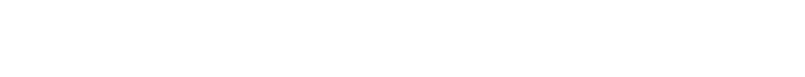

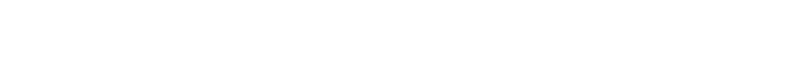

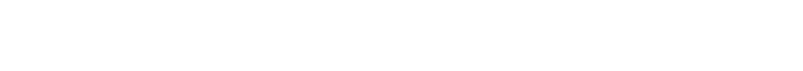
زراعة هذا المحصول. حقولين. كما لُٔفرت النتائج البحثية الواردة بالجدول(V) ع عن أن الإقتصادية المشجعة على التوسع فى زراعة محصول زهرة المهات

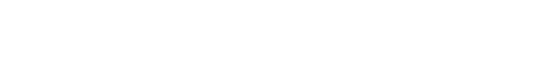

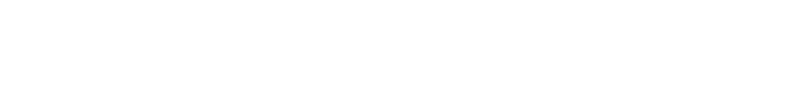

الزيق، الأمر الذى يظلب ضرورة الإهتداء بها عند وضع

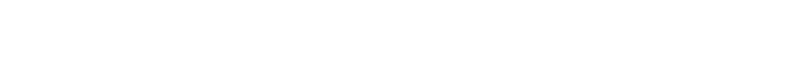

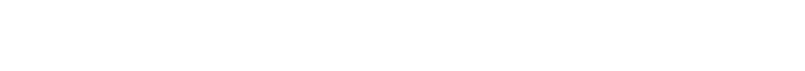
فـ زراعته.

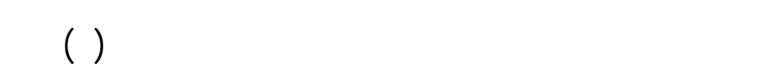

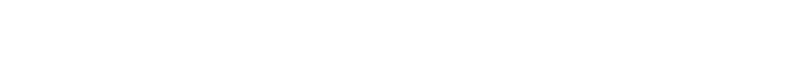

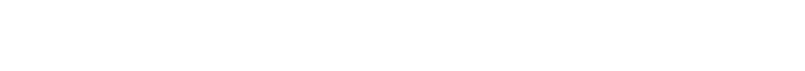

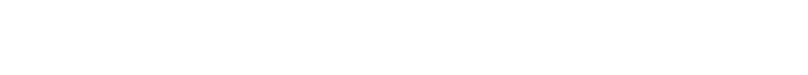

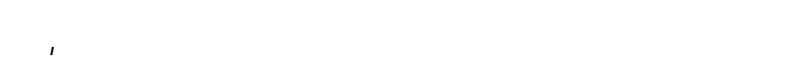

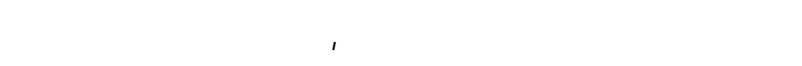

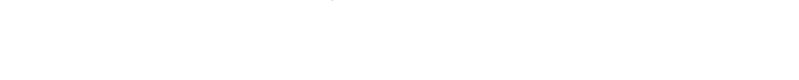

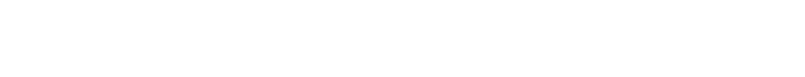

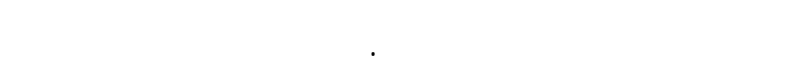

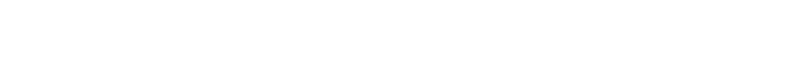

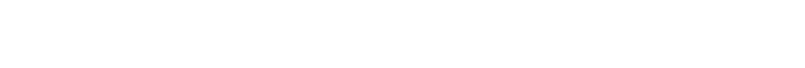
المحصول.

\section{r - درجة توفر مجموعة الفقوملت الإغتصالية الم ششجمة عل التوسع ف زراعة محصرل زهرة الثشس الزبق من وجهة قار المبحوثين:}

للتعرف على مدى توفر مل مقوم من مجموعة المقوملت الإقتصاية المشجعة على التوسع فى زراعة محصول زهرة

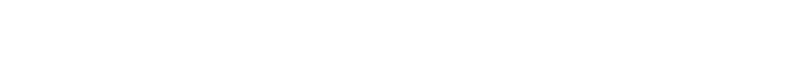

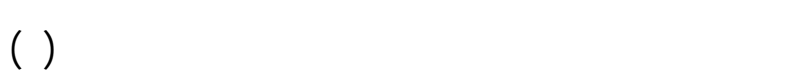

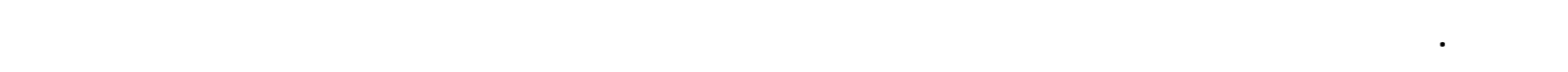
محصرل زهرة الششس الزبق.

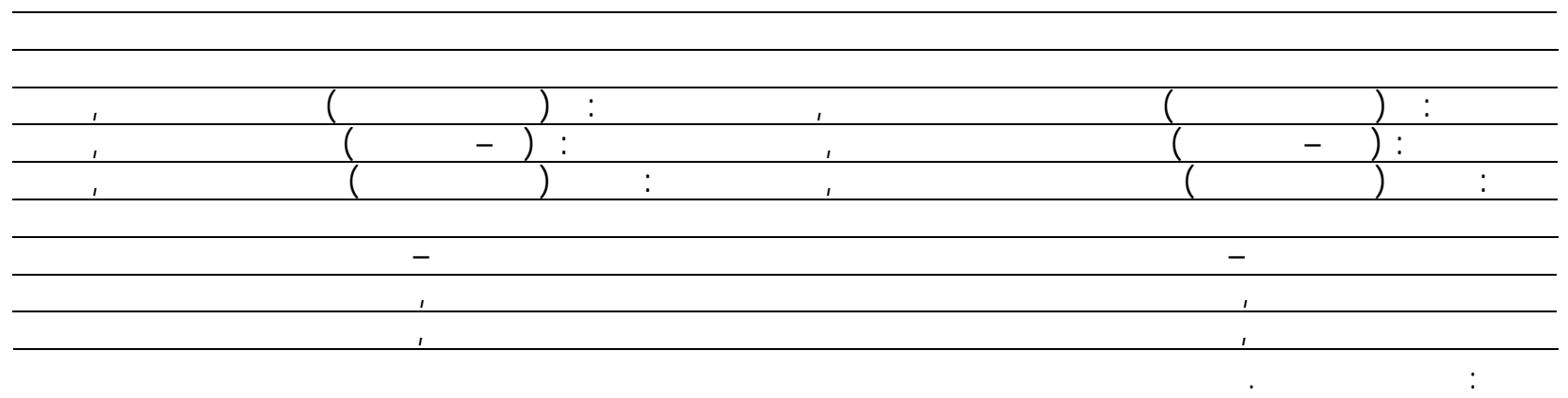




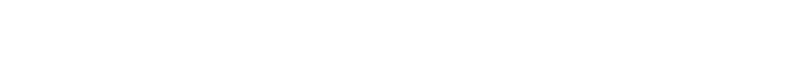

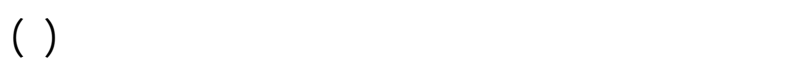

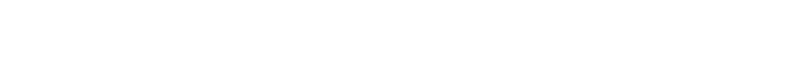

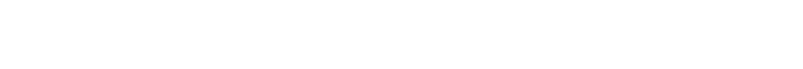

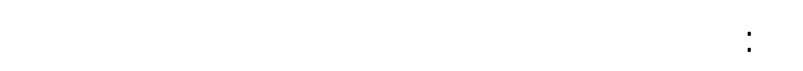

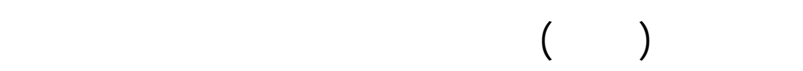

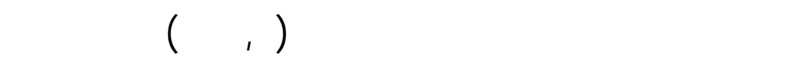

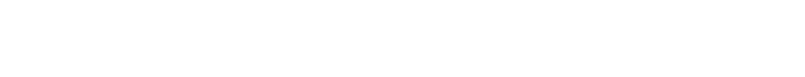

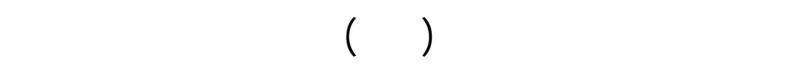

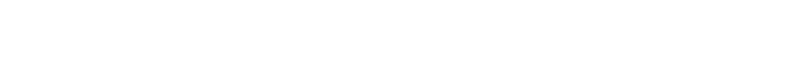

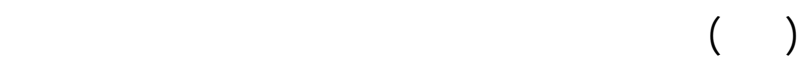

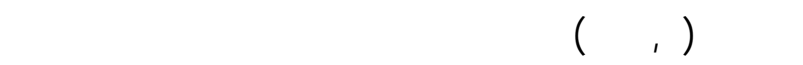

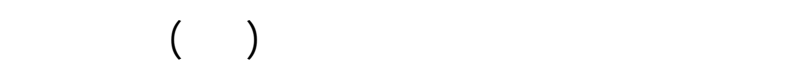

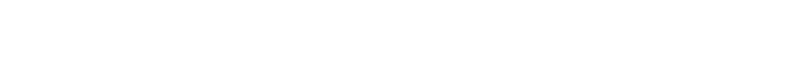

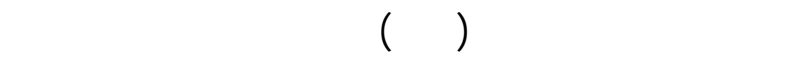

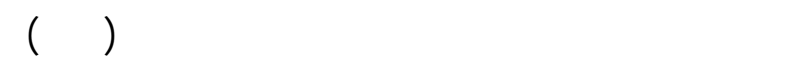

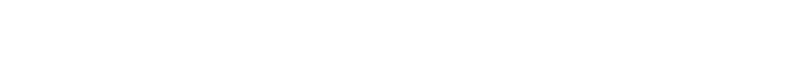

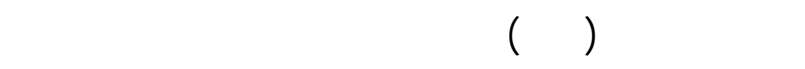

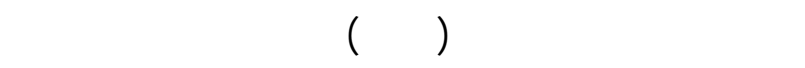

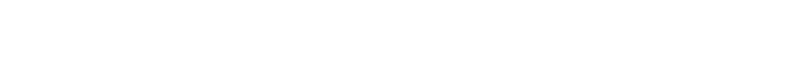

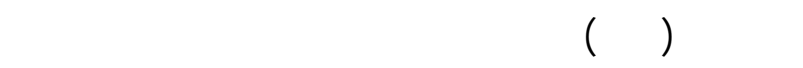
لحين تسويقه (AV,V)

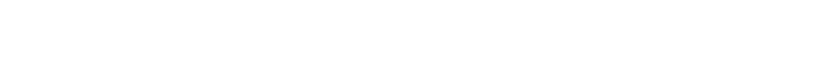
.$(\% 17)$

ويتضح من هذه النتائج أن جميع مجموء ـة المقوم لـ الت

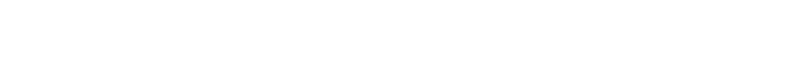

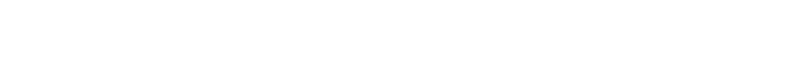

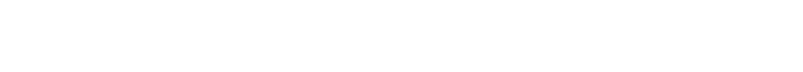

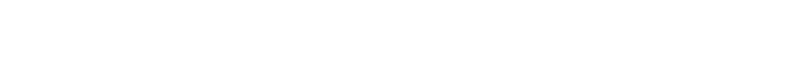
الأمل، أملاً فى تحفيز الزراع على التوسيع فى زراعة هذا المحصول. - المل

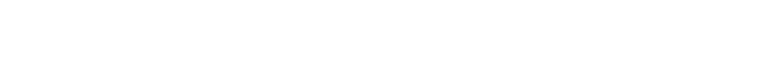

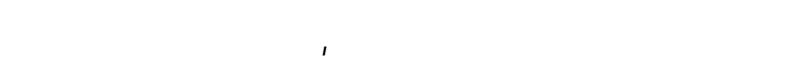

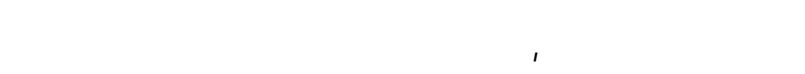

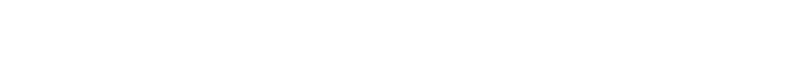

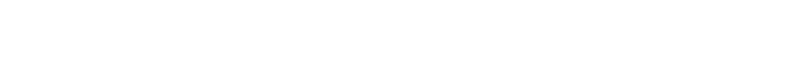

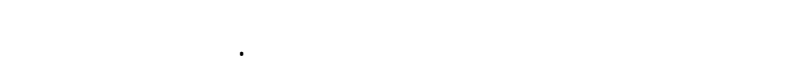

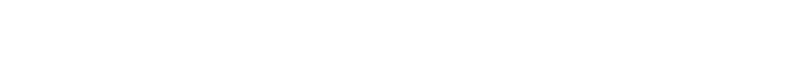

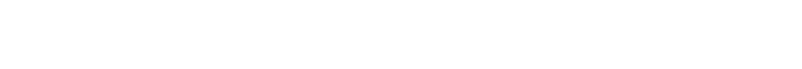
على التوسع فى زراعة هذا المحصول.

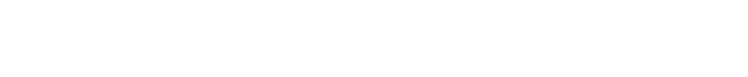

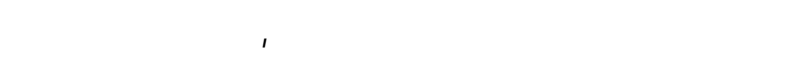

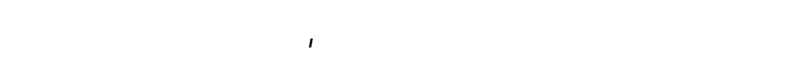

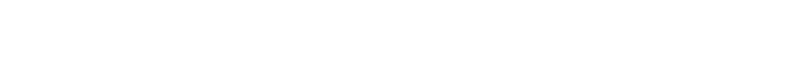

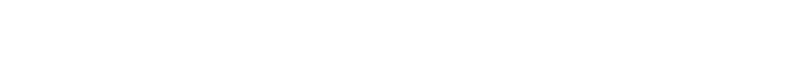

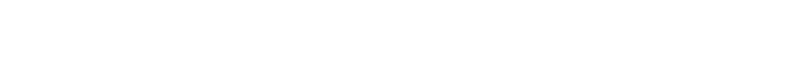

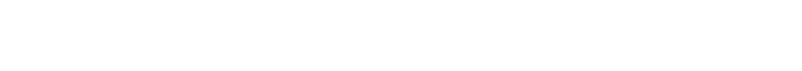

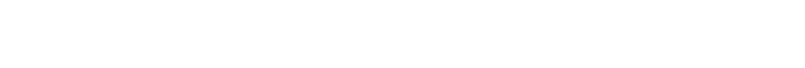

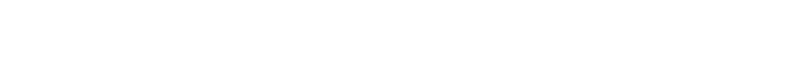

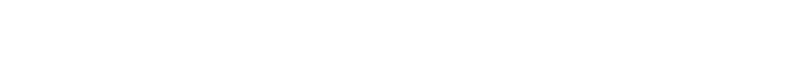

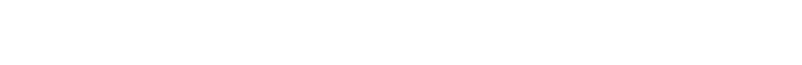

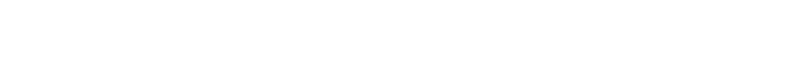
زراعته.

رلبهاً - ررجة أهمية وتوفرمجموعة المقوملت الت سسوقية

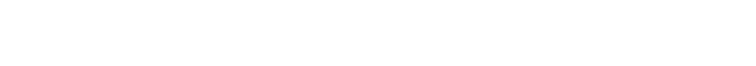
اللثسس الزيق من وجهة ظار المبحوثن: 1 - ررجة ألهمية مجموعة المقوملت النسوقية الم ششجعة عل التوسع ف زراعة محصط زهرة اللثس الزبق الزبق من وجهة ظلر المبحوثن: بلسإنتراض مدى أهمية كل مقوم من مجموعة المقوملت التسوقية المشجعة على التوسع فى زراعة محصول زهرة 


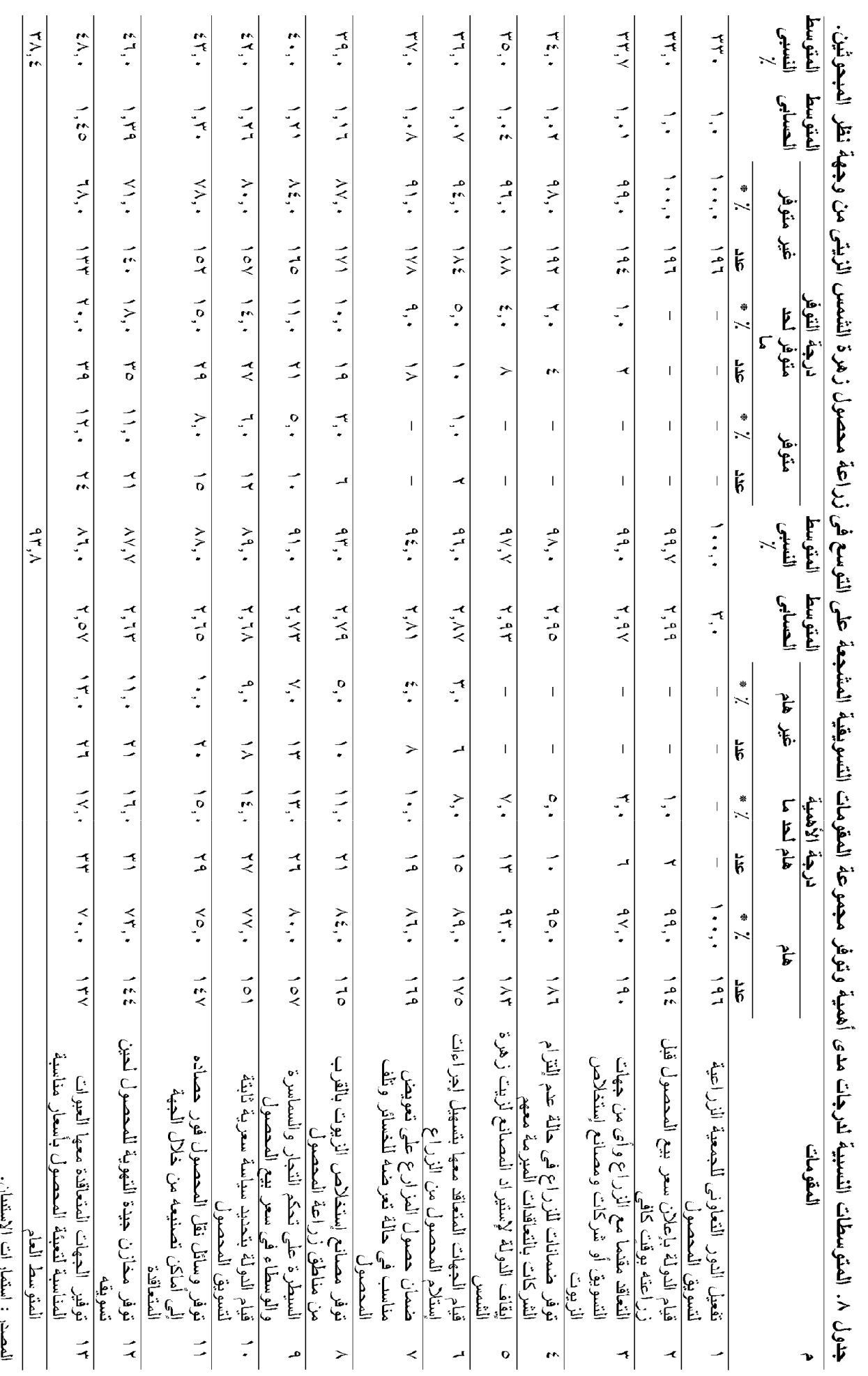


المحصول(بّ\%٪)، وقيلم الدولة بإعلانسعر بيع المحصول

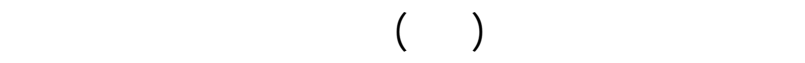

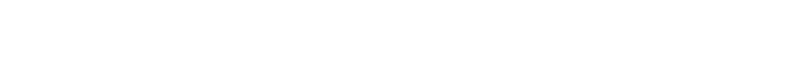

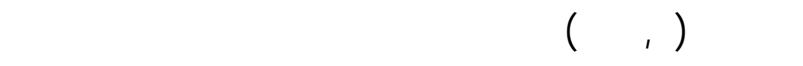

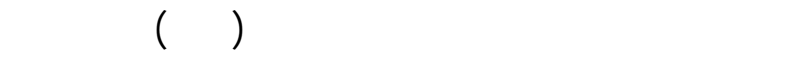

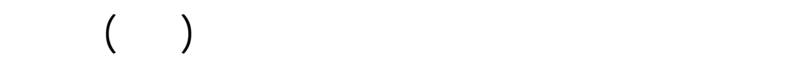

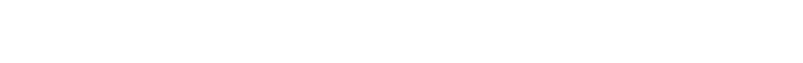

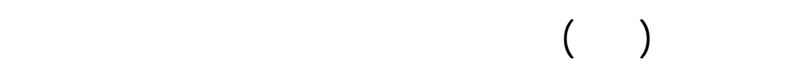

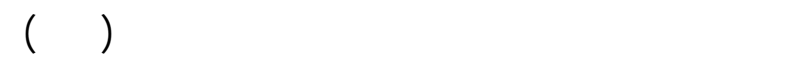

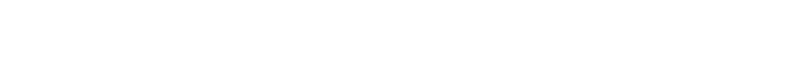

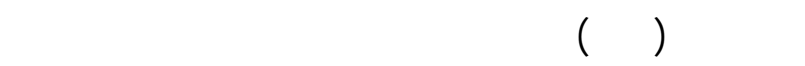

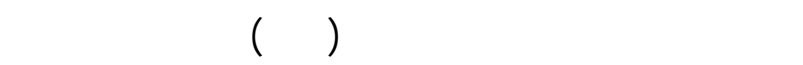

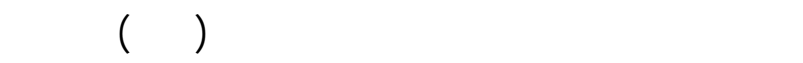
وسالل نل المحصول فور حصاه إلى أملكن تصنيعه مه ن

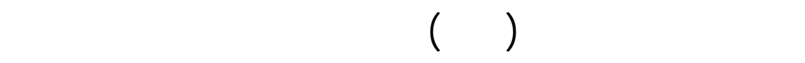

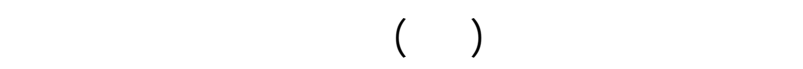

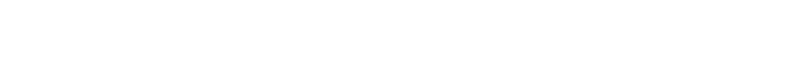
منلسبة (عی)٪).

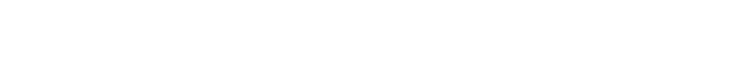
التسوقية المشجعة على التوسع فى زراعة محصول زهرة اللشهس الزيق كلتت درجلت توفرها منخفضة،
كما لظٔلهرت النتائج البحثي ـة الـ ـوارة بالج دول(و) أن

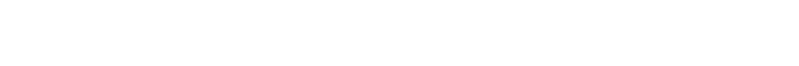
التسوقية المشجعة على التوسع فى زراعة محصول زهرة المعنة اللشهس الزيق من وجهة ظار المبحوثين قد تراوحت ما بين

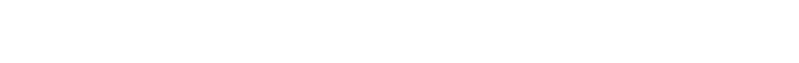

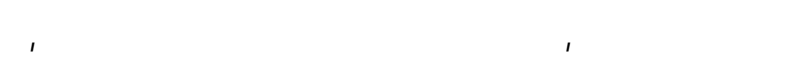

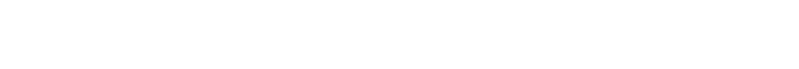

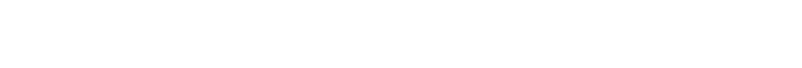

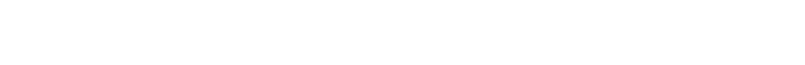

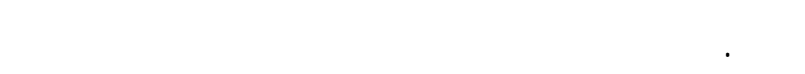

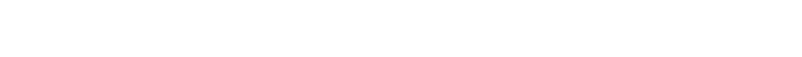
تشجيعهم على التوسع فى زراعة هذا المحصول.

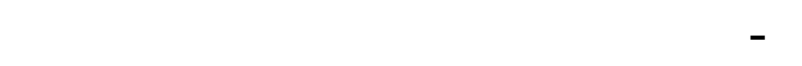

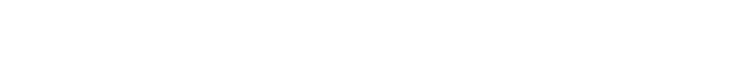

\section{من وجهة ظلر المبحوثن:}

للاقوف على مدى ترؤركل مقوم من مجموعة المقومات التسويقية المشجعة على التوسع فى زراعة محصول زهرة

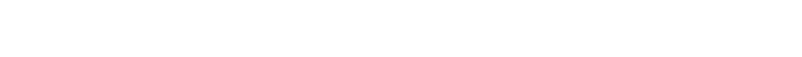

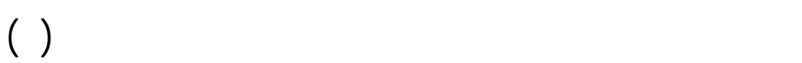

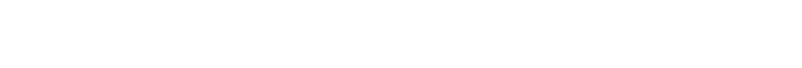

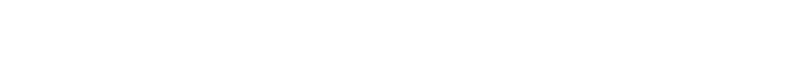

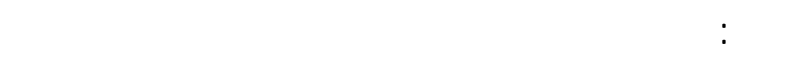

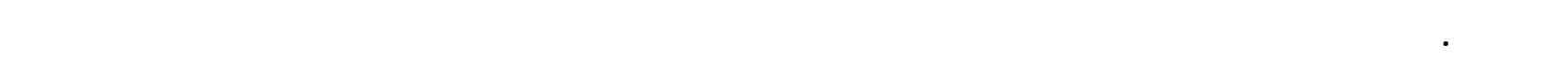
محصط زهرة اللثعس الزيق.

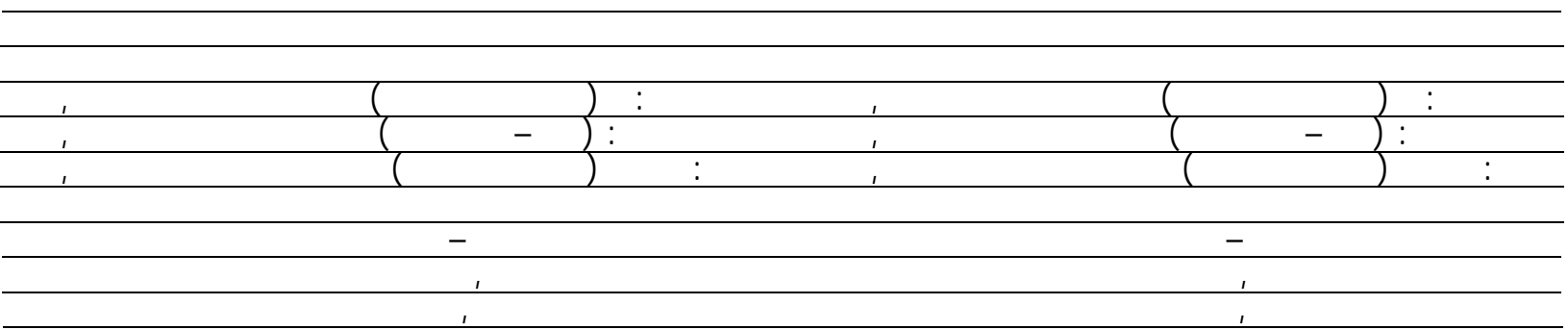


خلمسأ - مصادر المعلوملت الق يسق منها المبح وشبن معلوماتهم عن زراعة محصط زهرة الثشس الزبق:

أوضحت النتائج البحثي ـة ال _وارة بالج دول( · ( ) أن

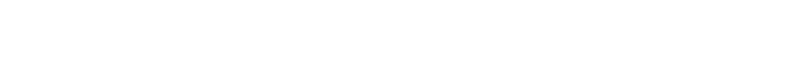

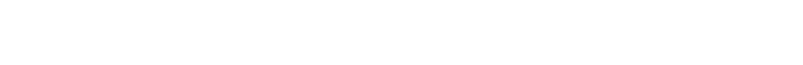
لإستجابك المبحوثن عليها، وذلك على النحو التاله: تجار

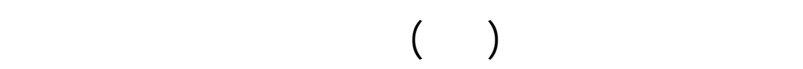

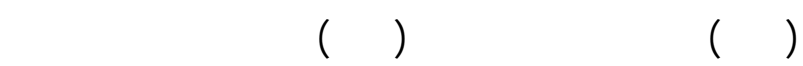

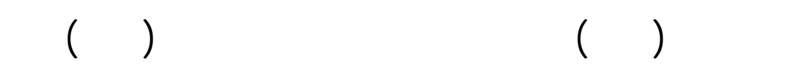
إخصائى المحاصيل الزيتية (0ع٪)، تله ذالك الإجتماء لت الت

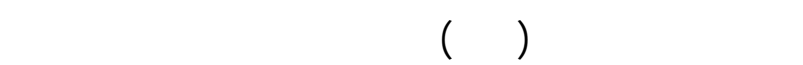

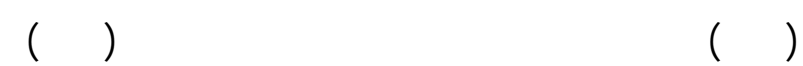
ولخيرً التيفزيون (IV) (IV).

وتشير النتائج اللسابقة إلى مدى إهتملم وإعتماد المبحوثنين

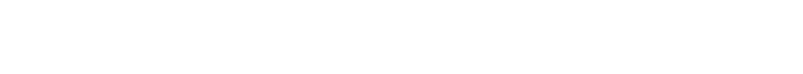

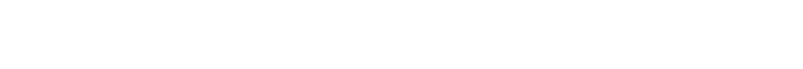

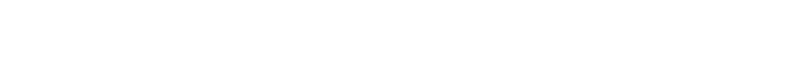

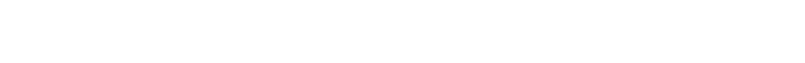

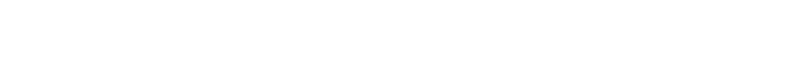

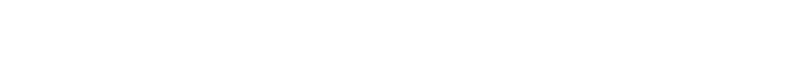

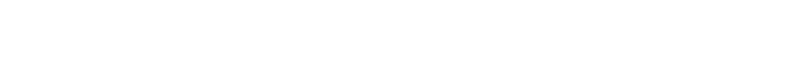

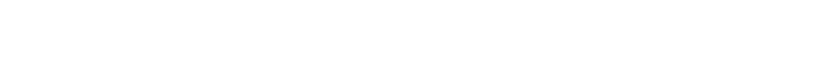
إعتماد هولاء المبحوثن على المؤسست والهيئت كمصادر

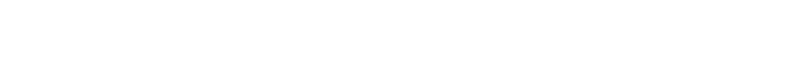
المحاصل الزيتية، والإجتماء لت والن دوات الإيش ادية،

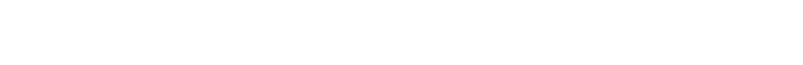
والتيلفيون، ويمكن إرجاع ذلك إلى تحنف دور تلك المصادر

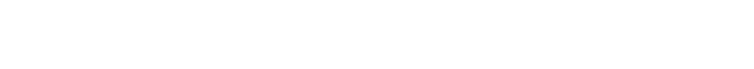

الأمر الذى منشأُه ضرورة لُخذها فى الإعتبارعند بناء الغطط والإستراتيجيلت الهادفة لزياة توفير هذه المقوملت، الفينه

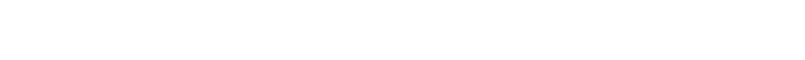

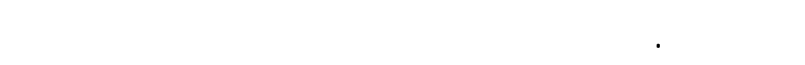

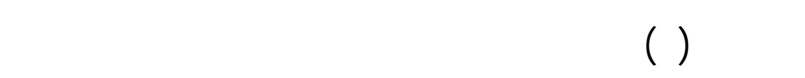

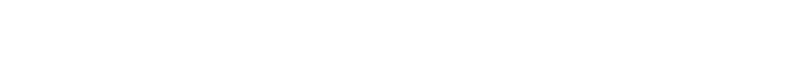

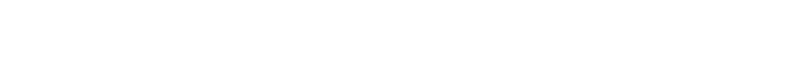

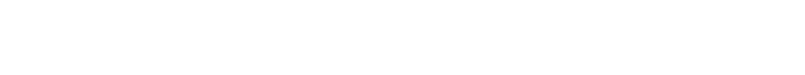

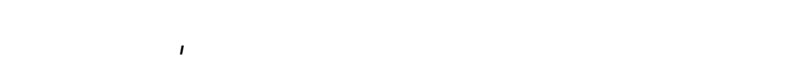

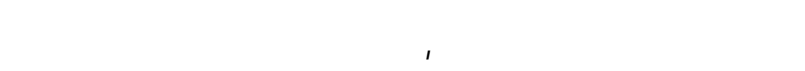
من المبحوثين يرون أن هذه المقوملت غير مت _وفرة، وأن

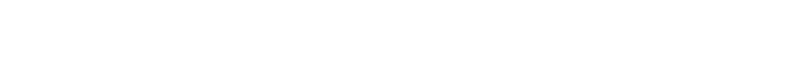

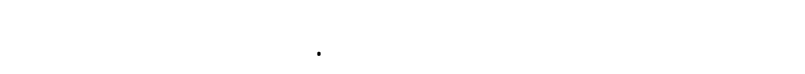

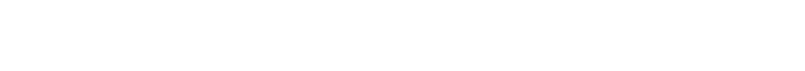

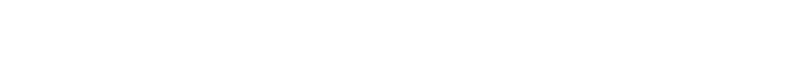
زراعة هذا المحصول. ويستنتج مماسبق أن المتوسط الذ سسب الع لم لأهمي ــة

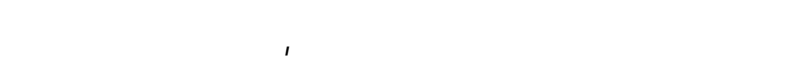

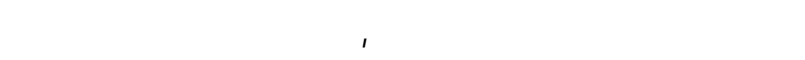

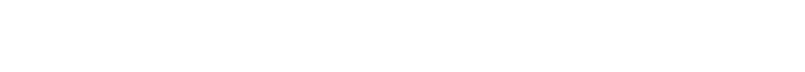

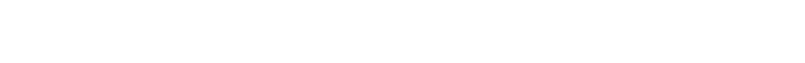

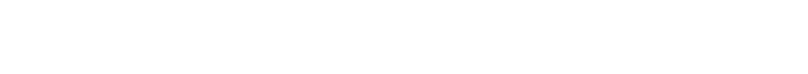
إنغفاض توفر هذه المجموعة، مما يستوجب م ن الق ائمين على للسيلسة التسويقية للمحاصل الزراعية بوزارة الزراعة التنسق مع مجلس المحاصل الزيتية، وكذا الجهات المتعاقد معها العل على وضع الغطط المنلسبة لتوفر تلك المقوملت

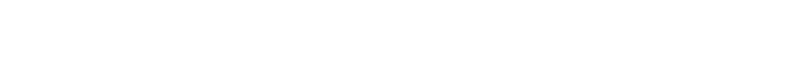

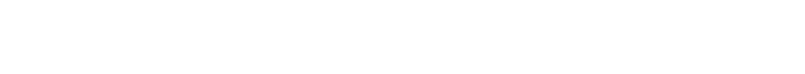
الزيق الهلم. 


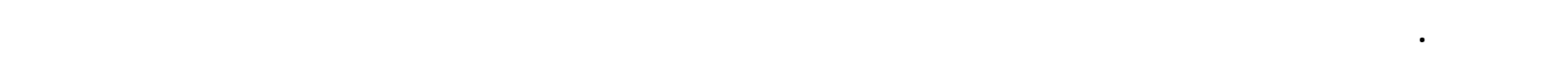

\begin{tabular}{|c|c|c|c|}
\hline$* * \%$ & | التكرار * & المصادر & م \\
\hline VY, & $\mid$ |हा & تجار المستلزمات الزراعية & 1 \\
\hline $7 \Lambda_{1} \cdot$ & IN & كبار الزراع بالقرية & $r$ \\
\hline $71, \cdot$ & 119 & الخبرة اللشخصية & $\mu$ \\
\hline$O V$, & $11 \varepsilon$ & الأقارب والجيران & $\varepsilon$ \\
\hline $0 \cdot, \cdot$ & 91 & مدير الجمعية الزراعية & 0 \\
\hline$\varepsilon 0, \cdot$ & $\Lambda 7$ & لخصائي المحاصيل الزيتية & 7 \\
\hline$\mu 7$, & V. & ألإجتماعلت والندوات الإِششادية & $\mathrm{V}$ \\
\hline$r \Lambda_{1} \cdot$ & 00 & الثُررت الفنية الإبشادية & $\Lambda$ \\
\hline$r{ }_{1} \cdot$ & El & المتخصصون بالبحوث الزراعية & 9 \\
\hline IV, & H & التيلفزيو & 1. \\
\hline
\end{tabular}

المصدر: لعإتمارات الإستبيلن.

* أتيحت الفرصة الكل مبحدوث نكر الكثر من مصدر.

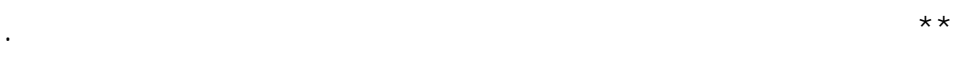

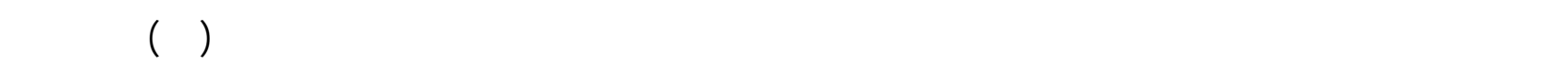

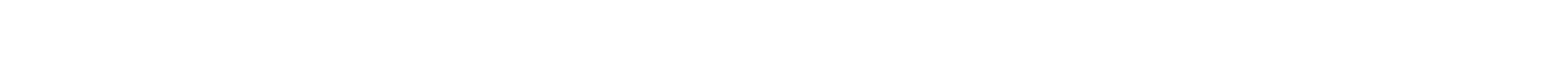

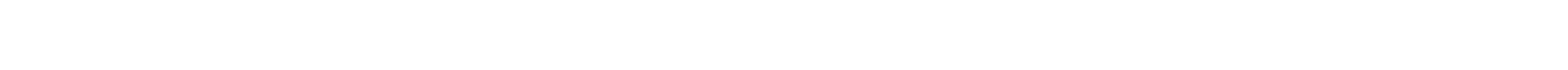

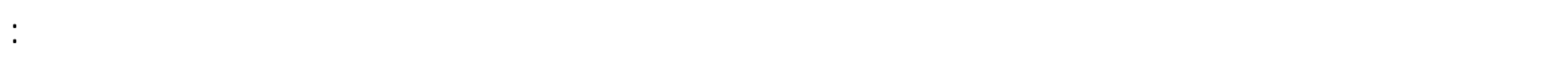

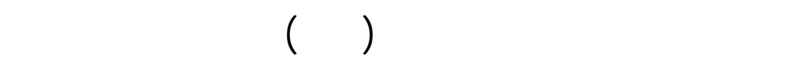

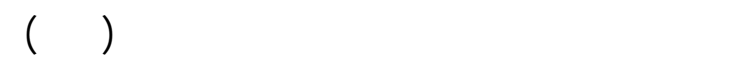

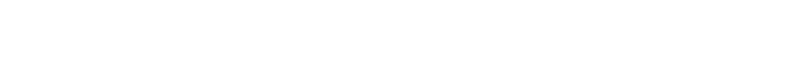
البحث.

عسالساً - المعوقل الت تولجه المبحوثين عند التوسع فم :

زراعة محصرل زهرة الثشس الزبتم ه ن وجه a

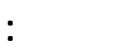

\begin{tabular}{|c|c|c|c|}
\hline$* \%$ & العدد & المعوقلت & م \\
\hline $9 \mathrm{~V}$, & 19. & إنخفاض سعر بيع المحصول & 1 \\
\hline 90, & 1117 & إرقفاع للسعار مستلزملت الإنتناج من مبيدات ولسمدة كيماوية & $r$ \\
\hline $9 \mu, \cdot$ & 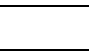 & قصور المعلوملت عن الأمراض والآفّت الهشرية التي تصيب المحصول & $\mu$ \\
\hline$\Lambda 9$, & $\mathrm{IV} \varepsilon$ & إنخفاض إنتلجية الفدان مقارنة بغيرهمن المحاصيل الأخرىى & $\varepsilon$ \\
\hline$\Lambda \mathrm{V}, \cdot$ & IV. & عنم قيلم الدولة بتحيدسعر ببع المحصول & 0 \\
\hline$\Lambda \mu$, & $17 \mu$ & قلة توفر النشرات الفنية الإيشادية الخاصة بالمحصول & 7 \\
\hline$\Lambda \cdot, \cdot$ & 10V & فلة توفرمصانع حكومية لإبستخلاص الزيوت النباتية & V \\
\hline $\mathrm{VV}, \cdot$ & 10 & عدم قيلم الدولة بتوفير ظعل الزراعة التعاقية للمحصول & $\Lambda$ \\
\hline Vr, & $|\varepsilon|$ & عدم قيلم الدولة بإلزلمشرككت إلستخلاص الزيوت بالحد من إِستيراد الزيوت الغذائية من الخارج & 9 \\
\hline $79, \cdot$ & $1 \% 0$ & تحكم التجار وللسملسرة والوسطاء فى أسعار تسويق المحصول & 1 . \\
\hline $7 \mu$, & I & وقلة توفر أصنفف القاوى الجية عالية الإنتلجية & 11 \\
\hline 01, & $1 \cdots$ & ضعف المعرفة بررق التحمل الصحبح على المحصول & 14 \\
\hline
\end{tabular}

المصدر: لمستمارات الإستبيلن.

* ق مسلب النب المئوية وفةًا لإجماله عدد المبحوثين والبالغ عددهم 197 مبحوثاً. 
بـ - قيلم قاع الخملت الزراعية بوزارة الزراعة بق حيم

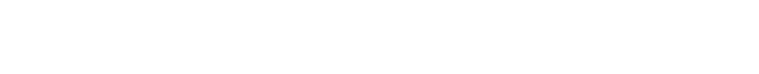
وقروض بفائة مخفضة.

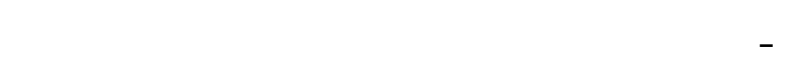

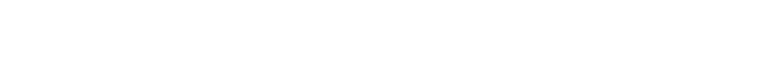

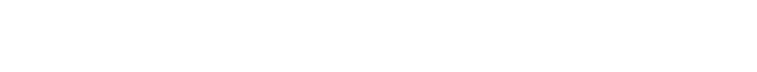
المشرية، وحصاد المحصول. 0 - قيلم الدولة بالتعاون مع مجل س المحاص لـيل الزيتي ية بتحيسيعر مجزي للمحصول.

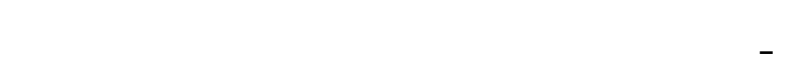
زراعته بوقت كلف. - V - Vيلم الدولة بإنشاء مصانع للإستخلاص الزيوت النباتي ة

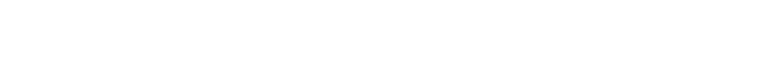
المحصل. لمل ه - العمل على تسويق المحصول بظطم الزراعة التعاقدية المنعسطرة ولحتكار التجار وللسملسرة للمحصول.

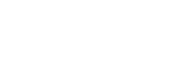

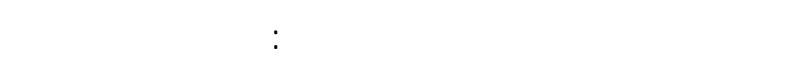

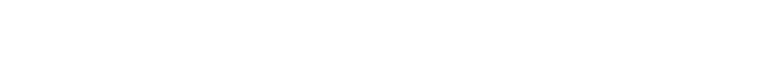
ملجمتير، كلية الزراعة، جلمعة عنشئهس.

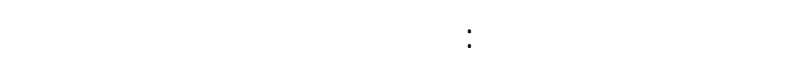
الجدية، الصحفة الزراعية، مجلد سجا، الإدارة العلمة للقفالة الزراعية، وزارة الزراعة ولستصلاح الأراض، الجيزة الزية.

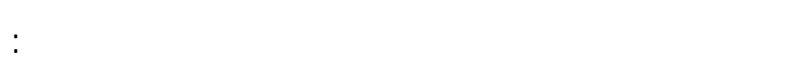

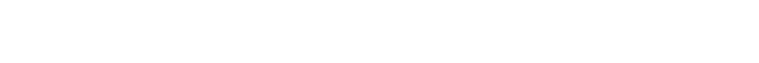
بالبحيرة، وزارة الزراعة ولستصلاح الأراضض.

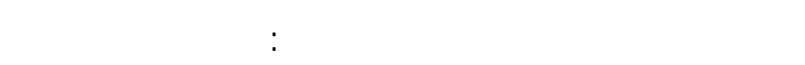

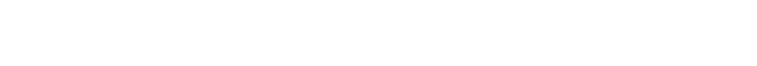

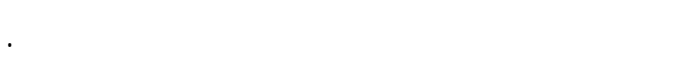

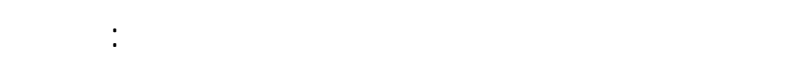

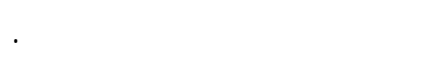

وقصور المعلوملت عن الأمراض والآو لت الح شررية

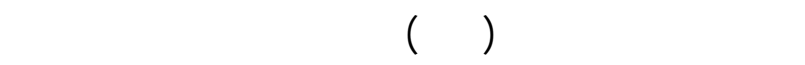

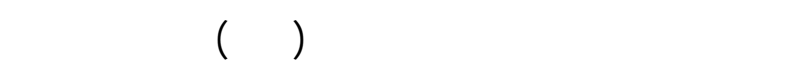

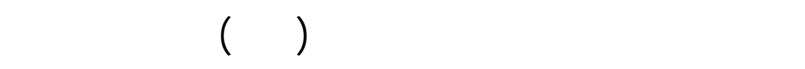

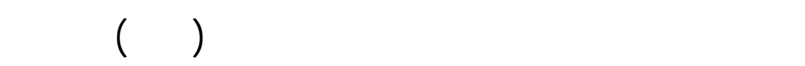

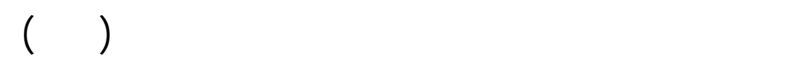

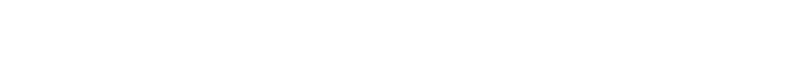
للمحصول(YVV)

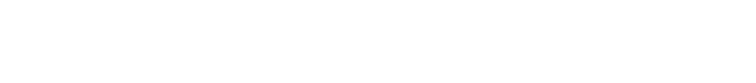

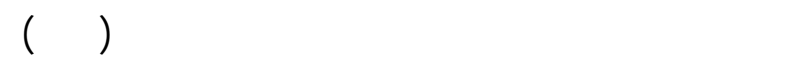

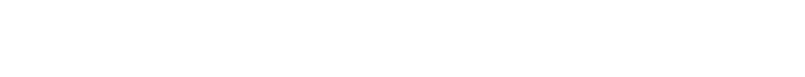

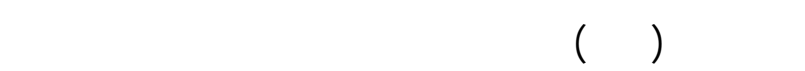

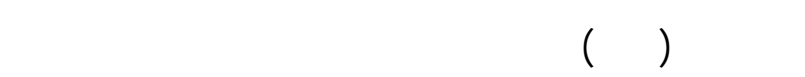
الصحبح على المحصول (101\%).

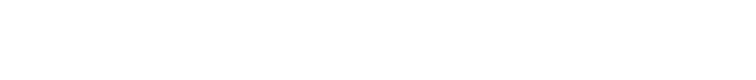

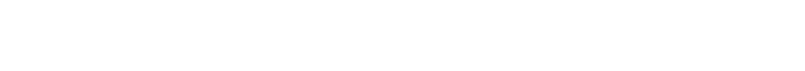

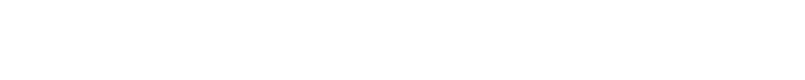

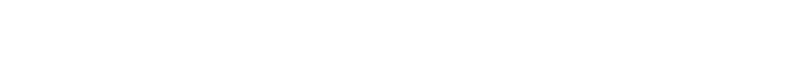

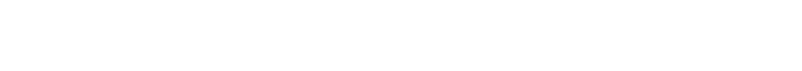

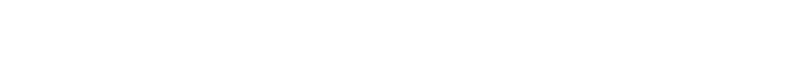
عل بعد لخر.

\section{النوصيلت}

بناءً على نتائج البهث للساجقة قم صياغة التوصيلت التالية:

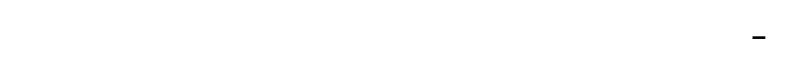

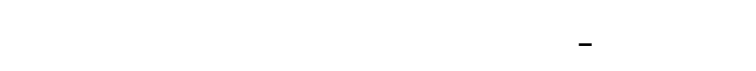
القاوى عالية الإنتلجية. r - قيلم وزارة الرى والموارد المائية بتوفير ميل الرى فى النتله فترة زراعة المحصول. - مالم وزاة المواد 
الرئيسية، المجلة المصرية للبحوث الزراعي ة، مجل دـ 10،

العدد ع. (العيسة.

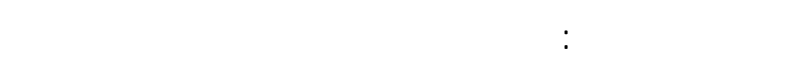

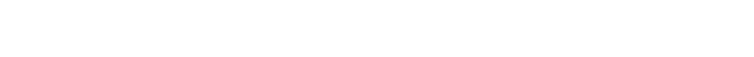
وزارة الزراعة ولِستصلاح الأراضی، الجيزة.

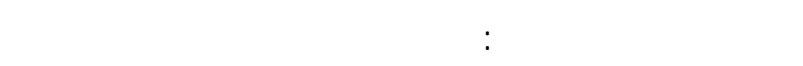

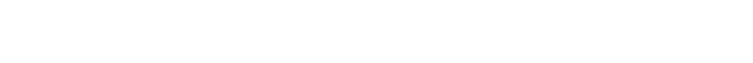
كلية الزراعة، جلمعة الأزهر.

غالى،سلوى عبد الفتاح محمد 10 • r:محددات عمليت إتخ الخاذ القرارات لزراعة وتسويق محصصل زهرة للثهس الزيق بين

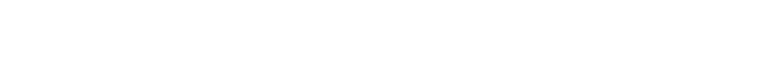
كتوره، كلية الزراعة، جلمعة لمنهور.

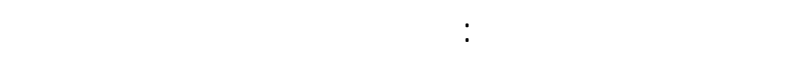
http;// kenanaonlin.com visited in 29/6/2015.مقع

مخائل، إمل صبهى، ومحمد عبد الرحمن الق صاص، وإيم ان

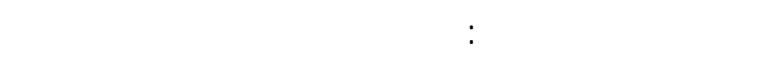

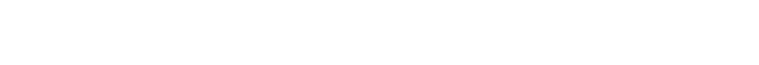

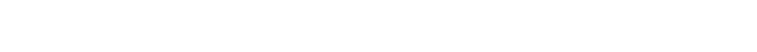
والإجتماعية الزراعية، كلية الزراعة، جلمع ـة المذ صورة، الفها مجلد ا، العدد (9)،سبتمبر.

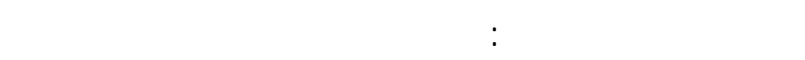

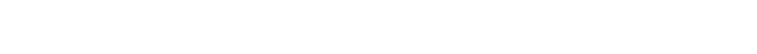

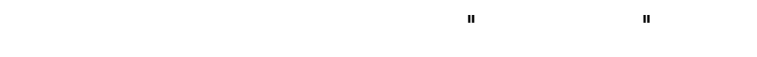
المصرية للتنمية وفل التكنولوجيا، عدد ع، يوليه.

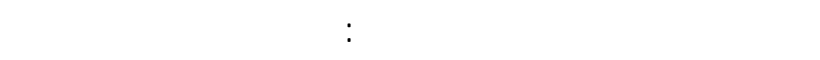
والإحصاء، بيانت بسمية غير مذ شورة، وزارة الزراء ولستصلاح الأراض.

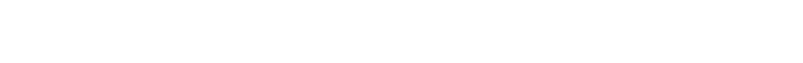

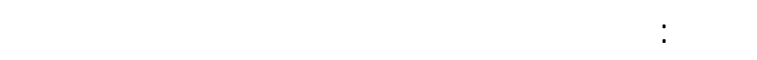

$$
\text { والشتوية، أغنطس، الجيزة. }
$$

krejcei, R.v. and Morgan, D.W, (1970): Determining sample size for reseaeeh activities, educational and psychological Measure Carolina U.S.A, MENT.
الخبير، الهسين محمد صابر رفعت، ونيلا ف i ـصف ف ـرج،

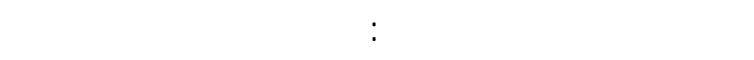

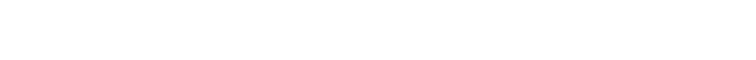

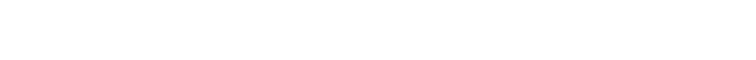
وزارة الزراعة ولستصلاح الأراضی، الجيزة.

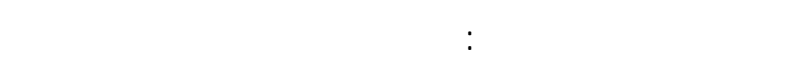

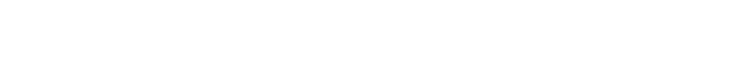

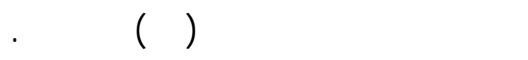

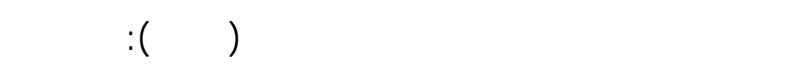

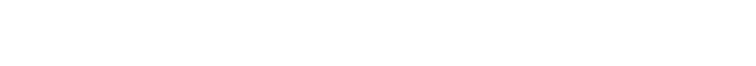

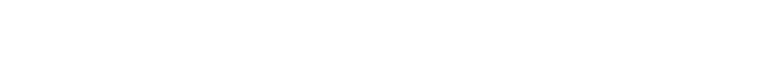
iوفمبر. اللشاذله، فوزى عبد العزيز، ودينا محمد لُحمد الشاءر، وممدوح البدرى محمد · 1 ·r: التنبؤ بإنتاج ولمستهلاك الزيوت ولمحدين النباتية

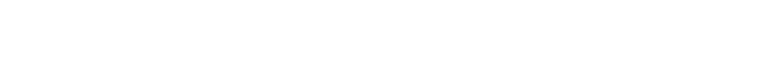

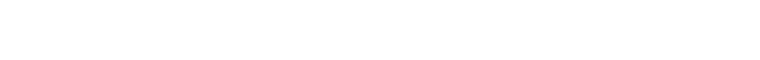

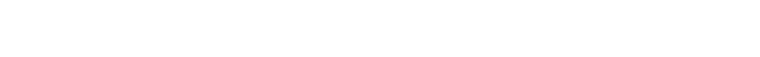

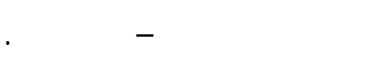

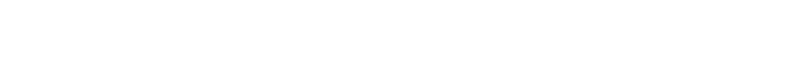

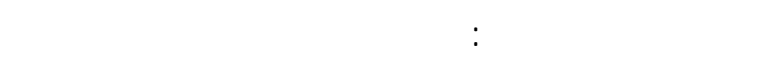

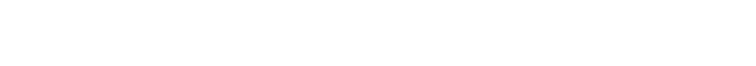

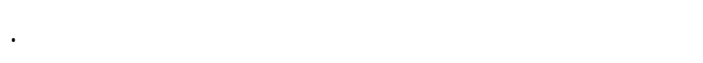

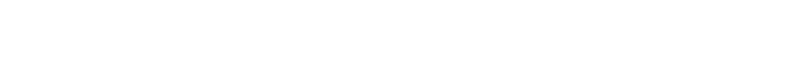
للإحصاءات الزراعية العربية، المجلد זّ، الخرطوم.

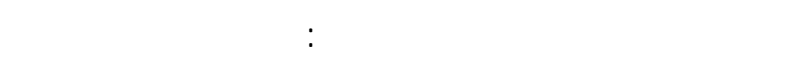

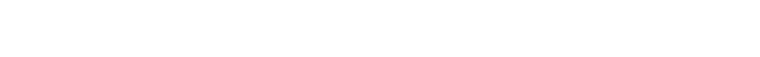

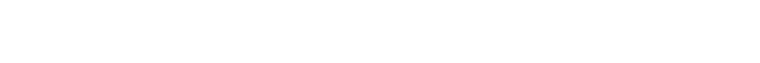
موقع

http;//aradina kenanaonlin.com visited in 15/7/2010 شلكر، محمد أحمد، ومحمد يوسف شلب،، وسمير عب ـد الفة ار

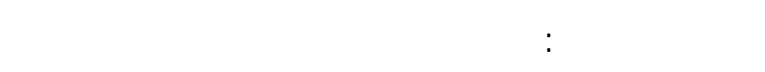

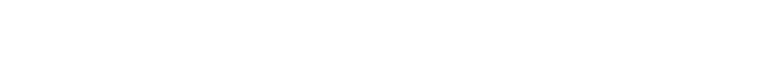




\title{
ABSTRACT \\ Constituents Encouraging the Expansion in Cultivation of Sunflower Oil's Crop among Farmers in Some Villages in Both Districts of Abu Elmatamer and Kafr Eldawar Beheira
}

\author{
Shady A. El- Tantawy, Hamza H. Mohammed, Abd El-Karim H.Zeyadh
}

This research aims mainly to determine the importance of encouraging ingredients of cultivation expansion of sunflower oil's crop from point of view of the respondents, and to determine degree of availability of these encouraging ingredients of cultivation expansion this crop from point of their view, and also, to identify the sources which respondents receive their information about its cultivation, as well as the obstacles facing them when expansion of cultivation of sunflower oil's crop from point of their view.

The research was conducted in Elbeherah governorate as one of the largest governorates in the Delta in terms of area which cultivate with sunflower oil's crop, by the same criterion it was selected two biggest districts, namely Abu Elmatamer, and Kafr Eldwar, followed by selection the largest villages of each district, they were villages: Alnemriah, Elgheatah in Abu Elmatamer, and Sidi Ghazi, Maroon in Kafr Eldwar district, data were collected using interviewing personal questionnaire from regular random sample amounted to 196 respondents according to equation of (Krejcie \& Morgan) among farmers of sunflower oil's crop of the four villages studied during the month of December 2015, Frequencies, percentages, arithmetic mean, standard deviation, and critical arithmetic mean, were used in data analysis and presentation of results.

\section{The main findings include:}

1- The respondents see that the four groups studied encouraging ingredients on expansion of the cultivation of the sunflower oil's crop, namely: productivity, Extensional, marketing, and economical, were important, where the general relative mean of importance of each group of them amounted to $84.3 \%, 89.1 \%, 91.8 \%$ and $93.8 \%$ respectively.

2- The respondents see that the four studied productive groups encouraging constituents on the expansion of the cultivation of sunflower crop were: productivity, extensional, and marketing, were available, where the general relative mean amounted of availability of each group of them $46.9 \%, 44.3 \%$, $40.2 \%$ and $38.4 \%$ respectively.

3- The most important sources of information that respondents receive their knowledge about cultivation of sunflower oil's crop are: agricultural input dealers, agricultural seniors in the village, personal experience, and relatives and neighbors.

4- The most important obstacles facing the respondents when expansion in cultivation of the sunflower oil's crop were represented in: low sale price of crop, high prices of production requirements foe each of pesticides and chemical fertilizers, lack of information about diseases of insect pests infesting the crop, low productivity per feddan compared to other crops, the State not determining the sale price of the crop, lack of extensional bulletins related to the crop, non- availability of governmental factories foe extracting plant oils, and the State not doing with to providing with the contract farming system to the crop. 